\title{
Review \\ Phycoremediation as a Strategy for the Recovery of Marsh and Wetland with Potential in Colombia
}

\author{
Yani Aranguren Díaz (D), Edy Monterroza Martínez, Laura Carillo García, María C. Serrano \\ and Elwi Machado Sierra *(D)
}

check for

updates

Citation: Aranguren Díaz, Y.;

Monterroza Martínez, E.;

Carillo García, L.; Serrano, M.C.;

Machado Sierra, E. Phycoremediation

as a Strategy for the Recovery of

Marsh and Wetland with Potential in

Colombia. Resources 2022, 11, 15.

https://doi.org/10.3390/

resources11020015

Academic Editors: Elena Rada

and Diego Copetti

Received: 23 November 2021

Accepted: 24 January 2022

Published: 29 January 2022

Publisher's Note: MDPI stays neutral with regard to jurisdictional claims in published maps and institutional affiliations.

Copyright: (c) 2022 by the authors. Licensee MDPI, Basel, Switzerland. This article is an open access article distributed under the terms and conditions of the Creative Commons Attribution (CC BY) license (https:// creativecommons.org/licenses/by/ $4.0 /)$
Unidad de Investigación Científica, Desarrollo e Innovación en Microbiología, Universidad Simón Bolívar, Barranquilla 080002, Colombia; yani.aranguren@unisimonbolivar.edu.co (Y.A.D.); edymonterroza3@gmail.com (E.M.M.); laumarce081307@gmail.com (L.C.G.); mary.csh98@gmail.com (M.C.S.)

* Correspondence: elwi.machado@unisimonbolivar.edu.co

\begin{abstract}
Colombia is the country with the sixth highest amount of water reserves in the world, and $25 \%$ of its territory is covered by wetlands. However, approximately $50 \%$ of the country's water is estimated to exhibit some type of contamination related to anthropic activities. An alternative for the treatment and the recovery of its bodies of water is the use of microalgae, unicellular, and mixotrophic microorganisms, as these bioreactors are highly adaptable to the environment, and their maintenance costs are minimal, because they feed on almost any substrate. In fact, different countries have already reported using microalgae as bioremediators for bodies of water. The use of these microphytes is efficient because they metabolize, degrade, or bioaccumulate heavy metals, pesticides, emerging pollutants, and antibiotics. In general, strategies relying on microalgae to eliminate pollutants are very similar to one another. For example, the first stage often includes a process of bioadsorption, consumption, degradation, and accumulation, wherein the microalgae use molecules generated from their own cellular metabolism. Some pilot studies focusing on the phycoremediation of marshes and other bodies of water have already been conducted in Colombia; however, more studies on process optimization, effectively leveraging the biodiversity of the existing microalgae, and better adapting microalgae to the region are still required.
\end{abstract}

Keywords: wastewater; biological contamination; chemical contamination; microalgae; bodies of water

\section{Introduction}

Marshes, known as flood plain lakes, are shallow, slow bodies of water $(\leq 10 \mathrm{~m})$, with temperatures rising above $25^{\circ} \mathrm{C}$ and rainfall exceeding $2000 \mathrm{~mm}$ per year that play an important role in the biogeochemistry and the ecology of tropical river systems. Life in these systems is well adapted to the spatial-temporal and physicochemical variations caused by extreme water level fluctuations, which depend on the degree of connectivity (direct or indirect) between the corresponding marsh and the rivers from which they receive water (during floods) or to which they discharge their water in (in dry periods) [1,2]. The hydrodynamic nature of these systems fosters complex primary and secondary production cycles in addition to being water reoxygenators, ecological refuges, a breeding and feeding area for local and migratory species, and, thanks to their high biological productivity, a significant means of sustenance for several economic activities [3].

Colombia reports 1900 marshes covering an area of 478,418 ha. Still, 80\% of this area is related to the Magdalena marsh system divided into four complexes: Bajo MagdalenaCanal del Dique, Delta rio Magdalena-Alto río Cauca y Magdalena medio, el sistema cenagoso de la depresión de la Momposina, and the Sinú river system [4].

The contamination of the marsh and wetland systems of the Colombian Caribbean region is largely associated with water management from their feeding natural (rivers) and anthropogenic sources (Figure 1A), some of which are easily distinguishable at the 
discharge site (direct), and others not as clearly visible, but causing environmental alteration and degradation (diffuse) [5]. Overall, the bodies of water feature different sources of contamination, which vary both in intensity and volume [6] and are closely linked to the expansion of agriculture, cattle ranches, mining, illegal plantations, and urban growth [7]. Wastewater is often a complex mixture of organic and inorganic materials coupled with artificial compounds. For example, $75 \%$ of the organic carbon found in wastewater is in the form of biomolecules such as carbohydrates, fats, proteins, amino acids, and volatile acids. Inorganic constituents include large concentrations of sodium, calcium, potassium, magnesium, chlorine, sulfur, phosphate, bicarbonate, ammonium salts, and heavy metals [6]. This large number of organic and inorganic substances affects water quality, thus generating an "eutrophic crisis", which is characterized by an excessive and uncontrolled proliferation of phytoplankton, plants, and cyanobacteria (blue-green algae).
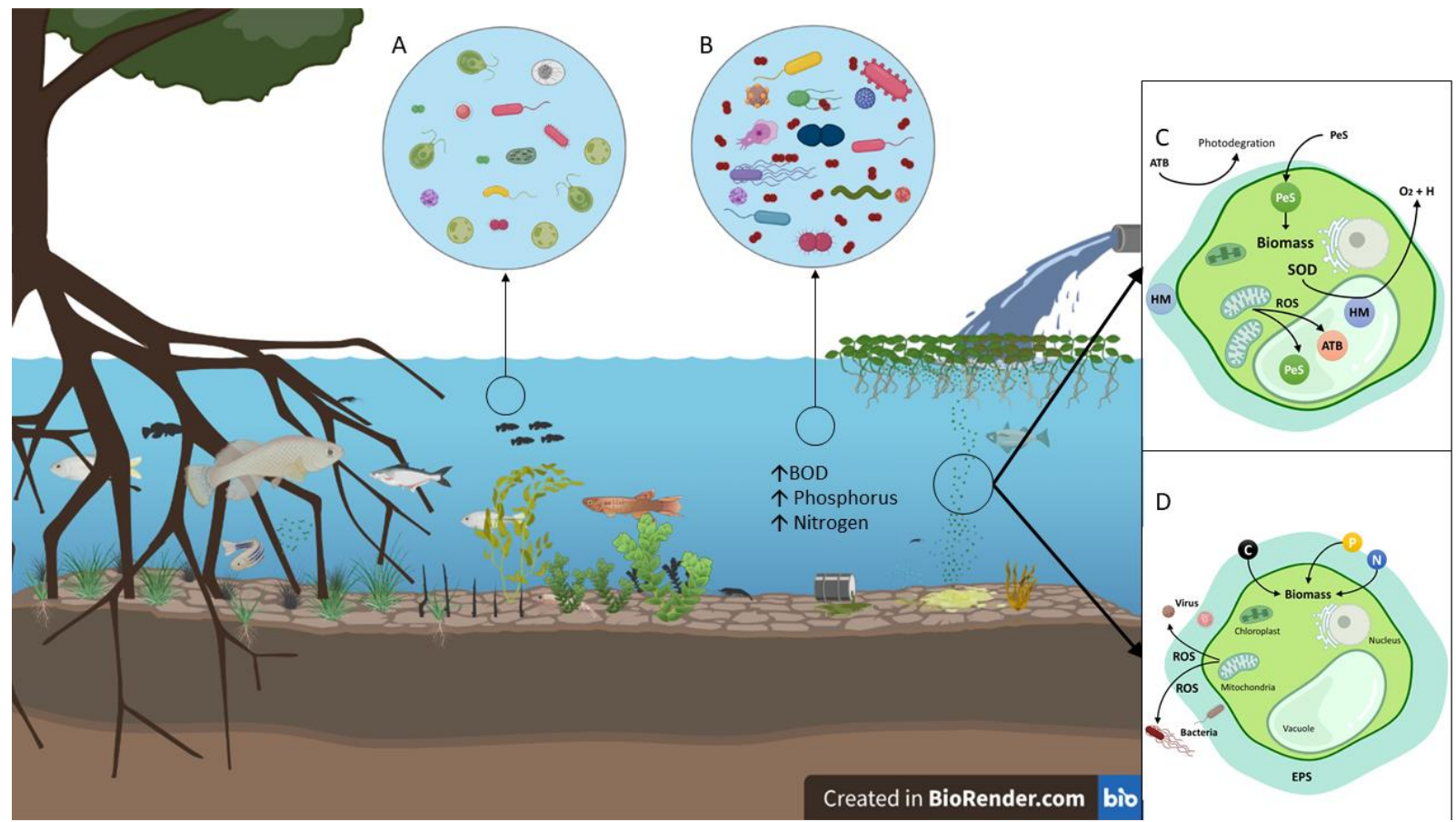

Figure 1. Effects from wastewater discharges on bodies of water, phycoremediation mechanisms. (A) In natural ecosystems, primary producers are in equilibrium, supporting the entire ecosystem; (B) in the eutrophication of bodies of water, there is an increase in the levels of phosphorus, nitrogen, and carbon. This generates proliferation of cyanobacteria and pathogenic microorganisms, which, in turn, triggers an increase in biochemical oxygen demand (BOD) and toxin biosynthesis, causing the death of the native fauna. (C) Phycoremediation mechanisms for antibiotics (ATB), heavy metals (HM), and pesticides (PeS); (D) microalgae biological control mechanisms against viruses and bacteria.

Perhaps the most visible effect of eutrophication (Figure 1B) is the generation of phytoplankton blooms on the surface, which constrain the penetration of light, hinder growth, and cause plant deaths, while, in turn, reducing the success rate of predators that require light to chase and catch their preys [8]. Furthermore, high photosynthesis rates can deplete dissolved inorganic carbon and raise $\mathrm{pH}$ to extreme levels, leaving large numbers of chemosensory organisms, which depend on the perception of dissolved chemical signals for their survival, without communication [9]. Ultimately, when these dense blooms die, microbial decomposition severely depletes the oxygen dissolved, thus creating a hypoxic environment, which is insufficient for sustaining most organisms [10].

Some algal blooms pose an additional threat, as they produce toxins (microcystin and anatoxin) that negatively affect the fishing industry and create significant risks to public health. Poisonings of domestic animals, wildlife, and even humans by toxic cyanobacteria 
blooms have been documented throughout the world, dating back to their first observation in Australia (1878), where cases of cattle killed by cyanobacterial blooms had been reported. In addition to posing significant public health risks, cyanobacteria have been identified as poor-quality food for most zooplankton grazers, thus reducing the efficiency of energy transfer in aquatic food webs [11].

In South America, blooms have been severely underestimated due to the lack of records and poor monitoring. One of the most notorious cases occurred in Brazil in 1996, where 52 people died from drinking microcystin-poisoned water. In Colombia, one of the first documented cases occurred in Ciénaga Grande de Santa Marta in 1971, where an unprecedented level of fish mortality was observed due to the proliferation of Anabaenopsis cyanobacteria. However, this was not an isolated event. In fact, this same event has been repeated several times in the same region: in 1985 and 1994 [12], and more recently in 2015 [13,14].

In addition to chemical contamination and direct environment eutrophication, microbial contamination is another issue that has become prominent in recent years. Marsh systems with direct sewage discharges are an ideal medium for the development of a wide range of microorganisms, especially bacteria, viruses, and protozoa. These microorganisms can cause diseases of different severity, ranging from gastroenteritis to severe diarrhea, dysentery, typhoid, or hepatitis. Most of these microorganisms are harmless (in fact, they are commonly used in wastewater treatments), but a few (excreted in large numbers by ill individuals) have the ability to survive and cause the aforementioned diseases. Some studies conducted on marshes denote a high microbial load related to fecal contamination (Table 1) and/or the prevalence of other enteropathogenic bacteria associated with autochthonous fauna, such as Vibrio [15], Citrobacter freundii [16], and Pseudomona aeruginosa [17].

In general, there are few studies related to marsh system contamination in the Caribbean region. Current information available is punctual and assesses few parameters (physical, chemical, biological, and ecological), and most of the studies available are gray literature and in many cases lack scientific rigor. Table 1, below, summarizes some research studies related to this subject matter. This type of marsh contamination and, in general, of continental bodies of water, is closely related to neighboring anthropic activity. For the marshes of the Colombian Caribbean, most reports indicate three major pollutants: coliform bacteria, pesticides, and heavy metals. These pollutants generate a eutrophication of the environment, with proliferation of pathogenic microorganisms, reduced primary production, genotoxic bioaccumulation, and, ultimately, loss of biodiversity.

Microalgae are unicellular organisms that convert the energy of solar radiation into chemical energy through photosynthesis. In terms of biomass, microalgae are one of the largest primary producers, and are responsible for at least $32 \%$ of global photosynthesis and oxygen production and $\mathrm{CO}_{2}$ sequestration [18]. The introduction of these microorganisms in the wastewater sector represented one of the most promising advances in recent decades [19,20]. This idea aims to use wastewater as a medium for the cultivation of biomass (microalgae) with high commercial value and, at the same time, contribute in a sustainable way to the purification of the effluent during the growth process. [21,22]. In this way, it would be possible to carry out both a bio-cleaning action of wastewater and a bio-recovery of nutrients, helping to mitigate the negative environmental impact of industrial and agricultural practices that depend significantly on a constant supply of macronutrients [23]. The commercial use of this technology was proposed more than 60 years ago by Oswald et al. [24]; however, it only recently received a significant boost in its implementation, thanks to the new sustainability policies. Biorefineries (as currently referred to as systems for the sustainable production of algae biomass used to generate subproducts and energy) are complex systems from an operational point of view, with operating costs higher than traditional wastewater treatment plants [23]; however, over time, they will be profitable, as long as some general rules are adopted, for example, (a) production and extraction of biocomposites with high added value, for which there is already a market [25]; (b) production of slow-release biofertilizers [26]; and (c) sustainable 
bio-recovery of heavy or precious metals and rare-earth elements through bioaccumulation and biosorption processes [27-29].

Microalgae have a wide range of applications in the pharmaceutical, food, animal, renewable energy, and cosmetics industries; it is estimated that there are approximately 45,000 to 100,000 species. Generally, and as they are not considered a taxonomic group, microalgae are eukaryotic unicellular organisms (with a size that can vary between 0.5 and $200 \mathrm{~nm}$ ), mixotrophic, with strong adaptability to the environment. This polyphyletic group of microorganisms is divided into subgroups called diatoms (Bacillariophyta), red algae (Rhodophyta), green algae (Chlorophyta), and blue-green algae (Cyanophyta) [30]. Currently, efforts are being made to standardize the double application of microalgae in the restoration of contaminated water bodies and the production of value-added products such as carotenoids, antioxidants, fatty acids, enzymes, polymers, peptides, toxins and sterols [31], and using industrial waste [32,33], livestock waste [34], agro-industrial waste and pesticides [35,36] as a substrate, making microalgae cultivation profitable [37]. Another promising approach is using these microorganisms as a phytoremediator of aquatic environments contaminated with antibiotics or toxic metals such as Aluminum, Nickel, Lead, Cadmium, Mercury, Tin, Arsenic and Bromine [38-41], and the elimination of pathogenic bacteria [42] and viruses [43]. In this review, we will delve into the physiological mechanisms used by microalgae to carry out these processes.

\section{Phycoremediation}

Phycoremediation refers to the use of macroalgae, microalgae, and cyanobacteria to eliminate or biotransformation of toxic and recalcitrant pollutants present in water and capture atmospheric $\mathrm{CO}_{2}$ (for environmental cleaning). This technology has ecological and economic advantages, mainly due to its high-efficiency adsorption, rapid process, and widely available resources [44]. To date, the relevant literature abounds in studies focusing on those strains with a high content of pigments, starches and especially lipids, the latter being used to obtain biofuels through transesterification processes [45]. However, microalgal species tend to have different physiological requirements related to temperature, $\mathrm{pH}$, the presence/absence of heavy metals and potentially toxic elements, the presence/absence of light radiation in the culture system, as well as the ability to perform an autotrophic, heterotrophic, or mixotrophic metabolism [23]. In this sense, microalgae, unlike other organisms (bacteria and fungi) used in the restoration of ecosystems, can perform several functions in parallel (metabolize, accumulate or adsorb pollutants, decrease organic load, capture $\mathrm{CO}_{2}$, and produce oxygen and added-value compounds and biomass). Although the removal, production or degradation rates seen independently are lower than those of other microorganisms, in systems based on bacteria or fungi, the final degradation products are organic acids and inorganic minerals that make up most of the sludge, the disposal of which becomes a problem [46].

There are three main strategies used by microalgae for environmental remediation, providing advantages compared to other biological processes that use microorganisms. The ability to remove polluting compounds is mediated by: (a) Biosorption-considered a passive process that allows immobilizing organic pollutants such as aromatic compounds and pesticides, by electrostatic bonding of the pollutant with the cell wall and the extracellular matrix [47]. Due to the microalgae's surface properties and retention capacity, its biomass is used as a biosorbent for diclofenac [48] and $\mathrm{Cr}+6$ [49] present in water. In many cases, physical factors ( $\mathrm{pH}$ and temperature) are among the essential parameters, since they affect the normal development of the microorganism and the pollutant, altering the pollutant's color, solubility, and viscosity. For example, in the phytoremediation of synthetic dyes, the biosorbent surface of microalgae has numerous functional groups such as carboxyl, hydroxyl, amino, and phosphates. Due to this, the net charge of the biosorbent depends on the $\mathrm{pH}$. If the $\mathrm{pH}$ drops, the biosorbent surface will have more positively charged sites, favoring the adsorption of anions due to electrostatic attraction. [50]. Therefore, at lower $\mathrm{pH}$, the biosorbent surface binds to anionic molecules [51]; (b) Bioaccumulation-it is con- 
sidered an active process where biomass captures organic and inorganic pollutants (heavy metals, pesticides, nitrates, sulfates and phosphates) and transfers them to the interior of the cells, eliminating them from the aqueous matrix [47]. This process is actively used to bioconcentrate metals such as $\mathrm{Zn}, \mathrm{Al}, \mathrm{Fe}, \mathrm{Cd}$ and $\mathrm{Cu}$ [39]. (c) Biodegradation-essential process to eliminate organic matter and small molecules present in the water through transformation and/or mineralization [52]; it has been observed that microalgae are capable of degrading pollutants and transforming them into intermediates, or improving the degradation rate of the microbial community present [53].

\subsection{Phycoremediation In Situ}

These techniques involve the treatment of contaminated substances at the site of contamination. They do not require any movement of the contaminated material and, therefore, no alteration of the matrix structure. Taking into account that slow ecosystems such as swamps and wetlands are large bodies of water, ex situ bioremediation techniques such as tubular photobioreactor, open raceway pond, and a two-stage hybrid system are more efficient in terms of quality since they can operate in more controlled conditions [54]. However, they have a limited maximum volume of cargo and investment costs ranging between 180,000 and 3,400,000 USD/hectare [55] for the open raceway pond and tubular photobioreactor, respectively, making this type of strategy economically unviable for the recovery of bodies of water. Ideally, these in situ techniques should be less expensive compared to ex situ bioremediation techniques; however, the cost of designing and installing some sophisticated equipment on-site to enhance microbial activities during bioremediation is a significant concern [55].

Some in situ bioremediation techniques include: (a) Biosparging, which is the injection of air (or oxygen) and nutrients (if necessary) into the contaminated area, generating an upward movement of volatile organic compounds to the unsaturated area, thus promoting biodegradation. The effectiveness of this technique depends mainly on the bioavailability and biodegradability of the pollutant. [55,56]; (b) Intrinsic bioremediation, also known as natural mitigation, which is a technique that involves passive remediation (without human intervention). The process is based on natural aerobic and anaerobic microbial processes to biodegrade pollutants, transforming them into less dangerous compounds. The absence of external force implies that the technique is less expensive. However, the process must be monitored to establish that bioremediation is continuous and sustainable; and (c) Bioaugmentation, which is the process of adding selected strains/mixed cultures to improve the catabolism of specific compounds, generally divided into two main strategies. Bioaugmentation is performed either by enrichment with native or indigenous microorganisms previously adapted and isolated from the site or enrichment with non-native microorganisms. This methodology is used in places with no active macro-organisms that degrade the contaminant. [57].

\subsection{Microbial Consortia}

Microalgae and bacteria are closely related (from a nutritional exchange point of view), covering many interactions ranging from mutualism/commensalism to competition/parasitism [58,59]. Generally, microalgae produce $\mathrm{O}_{2}$ and dissolve organic carbon that bacteria can use as an electron and energy acceptor. For their part, bacteria release $\mathrm{CO}_{2}$ during the degradation of organic matter, nitrogen, vitamin B, and siderophores, which are easily accessible to microalgae $[60,61]$. The substrate/metabolite interdependence promotes the growth of the associated groups and provides stability against environmental oscillations, minimizes the invasion of other species, and improves the global absorption of nutrients [62]. These interactions are not limited only to the exchange of nutrients, but also to communication through chemical signals, such as indole-3-acetic acid (IAA) and $\mathrm{N}$-acyl-homoserine lactones (AHL), which mediate a variety of collective behaviors and ecological functions, for example, acquisition of nutrients, construction of ecological niches (where the microalgae act as a secondary habitat, and the bacteria provide polysaccharides 
or proteins) and reproduction $[63,64]$. The antagonistic effects of microalgae/bacteria interactions cannot be ignored; in these cases, one microorganism controls the accelerated growth of the other. For example, bacteria produce toxic metabolites (mycotoxins and allelochemicals) and lytic enzymes that inhibit excessive growth of microalgae; and microalgae are capable of releasing exotoxins that act as bacteria growth-inhibiting compounds to maintain the balance of the community [64]. However, knowledge about the interaction mechanisms is limited at the moment [65], and is focused on understanding biological and physical interactions, with few studies having illustrated interactions at the molecular and biochemical level [58].

\subsection{Microalgal Biomass}

One of the main drawbacks of cultivation or bioremediation with microalgae is their collection and final disposal. Although there are multiple techniques available for separating biomass from the bulk of the crop, adopting a harvesting technique depends mainly on the application of the biomass produced and the energy requirement per unit of biomass production. In the preliminary step, collection techniques such as sedimentation, flocculation, filtration, electrocoagulation, and filtration are used to obtain a biomass suspension [66]. This biomass can be used as an alternative raw material (compared to the raw material that is typically generated from plants). The use of polluted water limits the application of the algae biomass produced [67]. In general, the microalgae biomass from contaminated waters can be used to produce alternative energies (biodiesel, biomethane, bioethanol, bioglycerol, polysaccharides and bioplastics). Therefore, removing contaminants would be necessary for use in specific applications. There are limited studies on the recovery of metals from coagulated-flocculated biomass. For this reason, it is imperative to study the recovery of other organic polymers from microalgae biomass [66].

\section{Biodiversity}

Microalgae are a very diverse group that includes prokaryotes (cyanobacteria) and photosynthetic eukaryotes located in three kingdoms: protozoa, chromista, and plantae [11]. Microalgae classification has been based on morphological, physiological, and ecological characteristics. However, molecular and ultrastructural characteristics have recently been included as part of their classification [68]. Given the differences between the International Code of Nomenclature of Prokaryotes and the classification systems used for eukaryotes, such as the International Code of Nomenclature for Algae, Fungi, and Plants, many authors exclude cyanobacteria from microalgae classification $[67,68]$. Still, a prokaryotic lineage is often identified within the group: Cyanophyta (blue-green algae), and nine eukaryotes: Prochlophyta, Glaucophyta, Rhodophyta (red algae), Cryptophyta, Chlorophyta (green algae), Euglenophyta, Chlorarachniophytes, Pyithophyta (dinoflagellates), and Chromophyta (heterokont algae) $[67,68]$.

These microorganisms are characterized by exhibiting chloroplasts or photosynthetic cell structures, and phycobiliproteins, such as chlorophylls and carotenoids [11,69,70]. They are widely distributed in environments as diverse as freshwater or marine, in surface waters, in water columns, deep waters, and sediments; and in terrestrial environments, in soils rich in organic matter, hot and cold sandy regions, and in extreme regions such as the Antarctica [11,69,71,72]. Microalgae are a part of plankton and play a critical ecological role at the bottom of the food chain. In fact, they account for approximately half of photosynthesis and oxygen production on the planet and play an essential part in carbon fixation [12,13,72]. In Colombia, although some metagenomics and microbial ecology studies have identified microalgae in rivers, marshes, and hot springs in different regions, there are very few studies on microalgal diversity $[13,73-76]$.

\section{Chemical Biodegradation through Microalgae}

Microalgae can degrade several chemical pollutants, such as heavy metals, contaminating gases, pesticides, antibiotics, and other toxic chemical compounds. For these purposes, 
and depending on the nature of the agent, microalgae use one of the following strategies to either degrade or internalize and bioaccumulate each agent (Figure 1C).

\subsection{Phycoremediation of Heavy Metals}

Heavy metals, such as arsenic, cadmium, chromium, lead, and mercury, are carcinogenic and may exhibit toxicity even in trace amounts, threatening ecosystems and human health. Within this context, there is an emerging trend of employing microalgae in the phycoremediation of heavy metals, due to their several benefits, including their abundant availability, affordable costs, excellent metal removal efficiency, and eco-friendly nature [75].

Meanwhile, even when microalgae are able to use heavy metals, such as boron, cobalt, copper, iron, molybdenum, manganese, and zinc, as enzymatic cofactors in cellular processes, other heavy metals, such as arsenic, cadmium, chromium, lead, and mercury, are toxic to them. However, due to the hormesis phenomenon, some low-toxicity heavy metals can even stimulate the growth and the metabolism of microalgae (Figure 1C).

In fact, microalgae use several self-protection strategies against toxicity, such as heavy metal immobilization, gene regulation, exclusion, chelation, antioxidant overexpression, and enzyme reduction; however, each strategy depends on the microalgae species and the nature of the metal. Below, we provide an overview of some of these strategies, but, for further information on this subject matter, please refer to Leong (2020) [75].

Table 1. Studies conducted in the main marshes of the Caribbean region.

\begin{tabular}{|c|c|c|c|c|}
\hline Location & Pollution Sources & Type of Assessment & Conclusions & Reference \\
\hline \multirow{4}{*}{$\begin{array}{l}\text { Grande de Santa Marta } \\
\text { Marsh-Magdalena }\end{array}$} & \multirow{4}{*}{$\begin{array}{c}\text { Domestic waste } \\
\text { Farming } \\
\text { Manufacturing industry }\end{array}$} & $\begin{array}{l}\text { Phosphorus } \\
\text { Nitrogen } \\
\text { Heat-resistant coliforms } \\
\text { Total suspended solids }\end{array}$ & $\begin{array}{l}\text { Eutrophication and } \\
\text { microbiological/fecal } \\
\text { contamination }\end{array}$ & [5] \\
\hline & & $\begin{array}{c}\text { Metal }(\mathrm{Pb}, \mathrm{Cd} \text {, and } \mathrm{Zn}) \text { determination } \\
\text { in sediments }\end{array}$ & High heavy metal levels & [77] \\
\hline & & $\begin{array}{l}\text { Determination of organochlorine pesticides } \\
\text { (lindane, heptachlor, aldrin, DDE, DDD, and } \\
\text { DDT) in sediments }\end{array}$ & $\begin{array}{l}\text { Contamination with } \\
\text { agrochemicals }\end{array}$ & [78] \\
\hline & & $\begin{array}{c}\text { Characterization of cyanobacteria and } \\
\text { their toxins }\end{array}$ & $\begin{array}{l}\text { Eutrophication and } \\
\text { contamination with } \\
\text { phycotoxins }\end{array}$ & {$[12-14,79]$} \\
\hline $\begin{array}{l}\text { Mir River Estuary-Pacific } \\
\text { Region }\end{array}$ & Trans-Andean pipeline & $\begin{array}{c}\text { Determination of Petroleum Hydrocarbons } \\
\text { equivalent of Chrysene (HP) and Polycyclic } \\
\text { Aromatic Hydrocarbons (PAH) }\end{array}$ & $\begin{array}{l}\text { contamination with } \\
\text { agrochemicals }\end{array}$ & {$[80]$} \\
\hline $\begin{array}{l}\text { La Mojana Region (San } \\
\text { Antonio Marsh, Machado } \\
\text { Marsh, and San Marcos } \\
\text { Marsh)-Sucre }\end{array}$ & Gold mining & $\begin{array}{l}\text { Determination of Mercury in sediments, fish, } \\
\text { hair, rice crops, and macrophytes }\end{array}$ & High heavy metal levels & [81] \\
\hline \multirow{4}{*}{ Ayapel Marsh- Córdoba } & \multirow{4}{*}{$\begin{array}{l}\text { Municipal and } \\
\text { industrial wastewater. }\end{array}$} & $\begin{array}{c}\text { Nitrogen } \\
\text { Phosphorus } \\
\text { Solids (total, suspended, sedimentable, } \\
\text { and dissolved) } \\
\text { Total coliforms }\end{array}$ & $\begin{array}{l}\text { Eutrophication and } \\
\text { microbiological/fecal } \\
\text { contamination }\end{array}$ & [82] \\
\hline & & $\begin{array}{l}\text { Determination of mercury in fish and marsh } \\
\text { inhabitants }\end{array}$ & High heavy metal levels & [83] \\
\hline & & Not specified & Mercury contamination & {$[84]$} \\
\hline & & Cyanobacteria characterization & $\begin{array}{l}\text { Eutrophication, high levels of } \\
\text { toxic cyanobacteria }\end{array}$ & [85] \\
\hline \multirow{2}{*}{ Mata de Palma Marsh-Cesar } & \multirow{2}{*}{$\begin{array}{l}\text { Municipal and industrial } \\
\text { wastewater } \\
\text { Farming } \\
\text { Cattle farming } \\
\text { Open-pit mining }\end{array}$} & $\begin{array}{l}\text { Tubificidae and Planorbidae counts- Indicators } \\
\text { of highly contaminated waters from organic } \\
\text { matter, polysaccharide waters, and hypoxia }\end{array}$ & eutrophication & [86] \\
\hline & & $\begin{array}{l}\text { Fecal coliforms } \\
\text { Total coliforms }\end{array}$ & $\begin{array}{l}\text { Microbiological } / \text { fecal } \\
\text { contamination }\end{array}$ & [87] \\
\hline \multirow[b]{2}{*}{ La Virgen Marsh-Bolívar } & Farming & $\begin{array}{l}\text { Organochlorine pesticides } \\
\text { DT, DDE, and DDD } \\
\text { Heptachlor and methoxychlor }\end{array}$ & $\begin{array}{l}\text { Contamination with } \\
\text { agrochemicals }\end{array}$ & [88] \\
\hline & $\begin{array}{l}\text { Municipal and industrial } \\
\text { wastewater }\end{array}$ & $\begin{array}{l}\text { Total suspended solids } \\
\text { Ammonium } \\
\text { Phosphorus } \\
\text { Fecal coliforms } \\
\text { Total coliforms }\end{array}$ & $\begin{array}{l}\text { Eutrophication and } \\
\text { microbiological/fecal } \\
\text { contamination }\end{array}$ & [89] \\
\hline
\end{tabular}


Table 1. Cont.

\begin{tabular}{|c|c|c|c|c|}
\hline Location & Pollution Sources & Type of Assessment & Conclusions & Reference \\
\hline \multirow{3}{*}{$\begin{array}{l}\text { Mallorquín Marsh-Atlantic } \\
\text { Ocean }\end{array}$} & \multirow{3}{*}{$\begin{array}{l}\text { Municipal and industrial } \\
\text { wastewater } \\
\text { Farming }\end{array}$} & $\begin{array}{c}\text { Metal }(\mathrm{Hg}, \mathrm{Cd}, \mathrm{Cu}, \mathrm{Pb}, \mathrm{Cr}, \mathrm{Ni} \text {, and } \mathrm{Zn}) \\
\text { determination in sediments }\end{array}$ & \multirow{3}{*}{ High levels of heavy metals } & [90] \\
\hline & & $\begin{array}{c}\text { Metal }(\mathrm{Hg}, \mathrm{Cr}, \mathrm{Cd} \text {, and } \mathrm{Ni}) \text { determination in } \\
\text { sediments }\end{array}$ & & [91] \\
\hline & & $\begin{array}{c}\text { Metal }(\mathrm{Zn}, \mathrm{Cu}, \mathrm{Pb}, \mathrm{Cd} \text {, and } \mathrm{Hg}) \text { determination } \\
\text { in water }\end{array}$ & & [92] \\
\hline Miramar Marsh-Santander & $\begin{array}{l}\text { Municipal and industrial } \\
\text { wastewater } \\
\text { Farming }\end{array}$ & $\begin{array}{c}\text { Total suspended solids } \\
\text { Fats and oils } \\
\text { Metal determination }(\mathrm{Al}, \mathrm{Ba}, \mathrm{Hg}, \mathrm{Pb} \text {, and } \mathrm{Cd}) \\
\text { in water } \\
\text { Total coliforms and fecal coliforms }\end{array}$ & $\begin{array}{l}\text { Heavy metal contamination, } \\
\text { eutrophication, and } \\
\text { microbiological/fecal } \\
\text { contamination }\end{array}$ & [93] \\
\hline $\begin{array}{l}\text { Opón and Miramar } \\
\text { Marshes-Santander }\end{array}$ & $\begin{array}{l}\text { Municipal and industrial } \\
\text { wastewater }\end{array}$ & Phytoplankton and zooplankton & Eutrophication & [94] \\
\hline Soledad Marsh-Córdoba & $\begin{array}{l}\text { Farming } \\
\text { Cattle farming } \\
\text { Gold mining }\end{array}$ & $\begin{array}{c}\text { Metal }(\mathrm{Fe}, \mathrm{Mn}, \mathrm{Ni}, \mathrm{Cr}, \mathrm{Al}, \mathrm{Hg}, \mathrm{Pb}, \mathrm{Cd}, \mathrm{Cu} \text {, and } \\
\mathrm{Zn} \text { ) determination in water, fish, and } \\
\text { sediments }\end{array}$ & Heavy metal contamination & [95] \\
\hline La Quinta Marsh- Bolívar & $\begin{array}{l}\text { Municipal and industrial } \\
\text { wastewater }\end{array}$ & $\begin{array}{l}\text { Total coliforms and fecal coliforms } \\
\text { Metal }(\mathrm{Hg}, \mathrm{Cr} \text {, and } \mathrm{Cd}) \text { determination in } \\
\text { sediments }\end{array}$ & $\begin{array}{l}\text { Heavy metal contamination, } \\
\text { eutrophication, and } \\
\text { microbiological/fecal } \\
\text { contamination }\end{array}$ & [77] \\
\hline $\begin{array}{l}\text { Puerto Caimán } \\
\text { Marsh-Atlantic }\end{array}$ & $\begin{array}{l}\text { Municipal and industrial } \\
\text { wastewater } \\
\text { Cattle farming }\end{array}$ & Phytoplankton & Eutrophication & [96] \\
\hline \multirow{2}{*}{$\begin{array}{l}\text { Grande del Bajo Sinú } \\
\text { Marsh-Córdoba }\end{array}$} & \multirow{2}{*}{$\begin{array}{l}\text { Farming } \\
\text { Cattle farming }\end{array}$} & Organochlorine compounds in fish & $\begin{array}{l}\text { Organochlorine } \\
\text { contamination }\end{array}$ & [97] \\
\hline & & $\begin{array}{c}\text { Cyanobacteria evaluation and } \\
\text { characterization }\end{array}$ & $\begin{array}{l}\text { Eutrophication, high levels of } \\
\text { toxic cyanobacteria }\end{array}$ & [98] \\
\hline
\end{tabular}

The phycoremediation of heavy metals through microalgae is achieved using a two-stage system. The first stage is rapid passive extracellular adsorption (biosorption). The outer surface of the cell presents a large number of peptides and exopolysaccharides with uronic groups, as well as functional groups, such as amino, carboxyl, hydroxyl, imidazole, phosphate, sulfonate, thiol, and others, capable of binding to anionic and cationic species of different heavy metals. The second stage begins when the metal is internalized through positive diffusion, and phytochelatin biosynthesis (peptides and proteins rich in thiol groups) is activated. These peptides and proteins form metalloprotein complexes, which are subsequently stored in vacuoles (bioaccumulation), helping to control metal ion concentrations in the cytoplasm and minimizing their toxic effects [99]. To counteract the free radicals released by heavy metals during adsorption, microalgae synthesize antioxidant enzymes, such as ascorbate peroxidase, catalase, glutathione reductase, peroxidase, and superoxide dismutase (SOD), as well as nonenzymatic antioxidants, such as carotenoids, cysteine, ascorbic acid (ASC), glutathione (GSH), and proline. SOD acts as the first line of defense against superoxide anions by decomposing them into oxygen and hydrogen peroxide molecules. Hydrogen peroxide is further degraded by catalase into water and oxygen molecules [75].

An example of bioremediation used in bodies of water contaminated with heavy metals is provided by Sivasubramanian et al. [100], who used Desmococcus oivaceus in the treatment of chromium-rich sludge generated by the electroplating industry. Based on this, microalgae play a critical role as primary producers in aquatic ecosystems, and their absorption capacity is a big additional advantage. Chlorella vulgaris, Scenedesmus incrassatulus, Chlamydomonas reinhardtii, Scenedesmus obliquus, and Chlorella pyrenoidosa have the ability to reduce chromium (VI) concentrations by $42 \%$ to $100 \%$ through chromium reductase and a glutathione purifying molecule [101]. Table 2, below, lists other examples in which microalgae have been used to remove heavy metals. 
Table 2. Using microalgae to remove heavy metals from bodies of water.

\begin{tabular}{ccc}
\hline Name & Metal & Reference \\
\hline Chaetoceros calcitrans & Cadmium & {$[102]$} \\
\hline Chlorella vulgaris & Nickel, zinc, lead & {$[103]$} \\
\hline Scenedesmus obliquus & Cadmium & {$[104]$} \\
\hline Pithophora lanceolatum & Lead, mercury, cadmium & {$[105]$} \\
\hline Spirogyra hialina & Mercury, cadmium, lead, arsenic, and cobalt & {$[106]$} \\
\hline
\end{tabular}

\subsection{Pesticide Phycoremediation}

The increase in the population worldwide has generated agricultural activities to be increasingly intensive as they seek to satisfy the need for food of the different populations, becoming an important source of contamination for groundwater and surface water systems in different rural areas [107].

Microalgae can use a variety of organic pollutants, including pesticides, as an energy source (Figure 1C). Most of these compounds have recalcitrant chemical structures that are difficult to degrade, and in some cases, the degradation products are more toxic. Biodegradation of pesticides is determined by two groups of factors, the first relates to microorganisms including the presence and number of appropriate microorganisms, the contact between microorganisms and the substrate (pesticide), $\mathrm{pH}$, temperature, salinity, nutrients, light quality and intensity, available water, oxygen tension and redox potential, surface binding, presence of alternative carbon substrates and alternative electron acceptors. The second group of factors including chemical structure, molecular weight and functional groups of the applied pesticides, their concentration and toxicity and their solubility in water [108]. In general, pesticide degradation (it is a similar process for antibiotic degradation) is a multistep process that includes the initial attack on substances, which thereby transforms the most hydrophilic compounds. In general, this process is characterized by reactions of hydrolysis, reduction, or oxidation of hydroxyl groups. The most common reactions portrayed are carboxylation, hydrogenation, and ring cleavage. The enzyme responsible for this initial process is cytochrome P450 [109]; in the second phase, the enzyme glutathione protects cells against oxidation processes. These catalysts are developed with the junction between electrophilic compounds and glutathione, glucose, or malonate [110,111]. In general, identifying enzymes responsible for the biodegradation of these contaminants in biodegradation processes is a highly complex process and there are only a few investigations on the same [111]. There are several studies that use algae from Chlorophyta phylum (green algae), Rhodophyta (red algae) and Chromophyta, to degrade organophosphate pesticides such as methyl parathion, parathion, malathion, phorate, quinalphos and monocrotophos; however, it has been proven that microalgae-bacteria microbial consortia are more effective in degrading compounds, for example: the use of Chlorella sp. and Scenedesmus sp. to degrade organophosphates, pyrethroids and oxadiazole [112], Chlorella vulgaris in non-anoxic cultures showed a high long-term removal rate in 10 of the most used industrial pesticides (carbofuran, carfentrazone-ethyl, fludioxonil, phenmedipham, propamocarb and terbuthylazine, among others) [35]. Chlorella sorokiniana [113] and Coccomyxa subellipsoidea [114] break down organophosphates (paraoxon, malathion and diazinon) through a mechanism that requires the formation of reactive oxygen species (ROS)

\subsection{Emergent Contaminant Phycoremediation}

Water quality management aimed at human health protection has focused on eutrophication, suspended sediments, heavy metals, and human pathogens. However, there has been a recent growing concern about the presence of Emergent Contaminants (CE, for the Spanish acronym) in bodies of water. Mainly, ECs (emergent contaminants) are compounds of different nature (synthetic or organic chemicals) with a high degree of solubility and are 
potentially dangerous for humans and the environment. These compounds are typically classified into several categories including pharmaceuticals, personal care products, illegal drugs, artificial sweeteners, plasticizers, and flame retardants. There are three main approaches through which microalgae can bioremediate EC: bioadsorption, bioconsumption, and biodegradation. Microalgae bioadsorption occurs when ECs are adsorbed on cell wall components or organic substances excreted by cell. Bioconsumption involves the active transport of ECs into the cell, where they link to intracellular proteins and other compounds. Unlike bioadsorption and bioconsumption, which simply act as biological filters that concentrate pollutants, biodegradation involves the transformation of complex compounds into simpler molecules through catalytic metabolic degradation. This process can occur through two mechanisms, either by metabolic degradation, where the EC serves as a carbon source; or by cometabolism, where EC is degraded by cytochrome P450 enzymes and other enzymes, such as glutathione-S-transferase, SOD, catalase, glutamyl-tRNA reductase, and malate/pyruvate dehydrogenase [115].

\subsection{Antibiotic Phycoremediation}

Antibiotic contamination has attracted increasing attention in recent years due to the potential harmful risks it represents to the environment and human health. Although most antibiotic traces found in the environment were in relatively low concentrations, growing evidence has demonstrate that they exert negative ecological effects on organisms, constraining the proliferation of beneficial microorganisms, and altering the composition and the activity of the microbial communities. Meanwhile, an excessive and improper use of antibiotics could promote the development and the spread of Antibiotic Resistant Bacteria and Antibiotic Resistant Genes, thus creating strong selection pressure on human and natural microbial systems [116].

Antibiotic removal rates depend to a large extent on the species of microalgae. For example, the species of the genus Chlorella are effective for the degradation of cephalosporins, ceftazindin, cephradine, cephalexin, amoxicillin, azithromycin, enrofloxacin, florfenicol, and levofloxacin. Some antibiotics can also be removed by photodegradation and volatilization; however, for these processes to occur, very special conditions must be met, which are not common and are generally considered insignificant. The degradation of antibiotics by microalgae occurs in three steps: (a) rapid passive adsorption through physicochemical interactions between the cell surface and contaminants; (b) a transfer of molecules across the cell membrane; and (c) bioaccumulation and biodegradation within the cell [117]. The mechanism of antibiotic adsorption and internalization is practically the same as that for heavy metals, but the underlying biodegradation mechanisms can be classified into two categories: (1) metabolic degradation, in which the antibiotic acts as a standalone carbon source or as a microalgae electron donor/acceptor (Figure 1C); and (2) cometabolism, in which additional organic substrates both sustain biomass production and act as electron donors. For further information on this matter, please refer to Xiong, 2021 [116].

\subsection{Polycyclic Aromatic Hydrocarbons Degradation}

Combined contamination of xenobiotics in aquatic ecosystems represents an environmental issue due to the limited information on the reciprocal interactions between chemicals and their toxic mechanisms [118]. The carcinogenic and mutagenic potential of Polycyclic aromatic hydrocarbons (PAHs) is well known; therefore, their effects on aquatic organisms are a critical concern [119]. PAHs consist of two or more benzene rings fused in linear, angular, or cluster [120]; they are considered recalcitrant compounds due to their low solubility, relative stability, low volatility, and resistance to biological degradation [121].

Compared to bacteria and fungi, not enough attention has been paid to the biodegradation of PAHs by microalgae, despite their ubiquitous distribution, their central role in carbon fixation and renewal, and the recognition of their heterotrophic capabilities. The information on the relationship between heterotrophy of algae and biodegradation of xenobiotic compounds is less than the broad information on bacteria and fungi [122]. 
Several microalgae strains are known to have the ability to metabolize/transform different PAHs (naphthalene, phenanthrene, anthracene, benzopyrene) [123]. Generally, microalgae have three mechanisms for eliminating PAHs from the environment: (1) PAHs adsorption on the surface of algae cells depending on the active groups present on those surfaces; (2) accumulation of PAH within algae cells; and (3) transformation of PAH depending on enzymatic actions [122-124]. The enzymatic degradation of PAHs depends on the nature and structure of the aromatic compound. For example, Warshawsky et al. (1995) [125] evaluated the degradation of benzopyrene $(\mathrm{BaP})$ by Selenstrum capriconutum, discovering that the algae used a dioxygenase system (similar to the bacterial degradation systems of PAHs, but different from those of eukaryotic organisms) to oxidize the compound and convert it to glucoside ester sulfate conjugates. Benzene undergoes reduction followed by hydrolytic cleavage of the ring to produce aliphatic acids used in cell growth [124]. On the other hand, the biotransformation of naphthalene by Oscillatoria sp. produces four primary metabolites, 1-naphthol, 4-hydroxy-4-tetralone, cis-naphthalene dihydrodiol and trans-naphthalene dihydrodiol in concentrations that were not toxic. However, total naphthalene degradation was low, ranging from 1 to $1.9 \%$ [126,127].

In the biodegradation of Fluoranthene (FLT) by Chlorella vulgaris, enzymatic studies confirmed that the enzyme involved in the metabolism of FLT was catechol 2,3-oxygenase and peroxidase (POD). The analysis showed that growth rate, biomass, chlorophyll, carbohydrate and protein content were negatively affected. In contrast, lipid and carotenoid content increased significantly [123], a similar study where the degradation of phenol and its methylated homologues by Ochromonas danica showed that the enzyme catechol 2,3-oxygenase is directly involved in the degradation of this type of compound [124]. For a more in-depth description, refer to these articles [122-124,128,129].

\section{Biological Contaminant Phycoremediation}

The wastewater environment is an optimum medium for a wide range of microorganisms, especially bacteria, viruses, and protozoa. Most are harmless and, in some cases, are used in the biological treatment of wastewater. Nevertheless, wastewater also contains pathogenic microorganisms, which are excreted in large numbers by ill individuals and symptomatic carriers. For example, wastewater can contain the bacteria that cause cholera, typhoid fever, and tuberculosis, the viruses that cause infectious hepatitis and COVID-19, and the protozoa that cause dysentery [6].

\subsection{Bacteria Removal}

The photosynthetic activity of microalgae results in an increase in Dissolved Oxygen (DO) and temperature, which decreases the number of pathogens found in the body of water. The increase in DO promotes oxidative stress from the production of Reactive Oxygen Species (ROS) that damage cellular components, such as the proteins and the lipids of the cell membrane, and DNA, which increases the removal of pathogens (Figure 1D) [130,131].

During microalgae proliferation, the $\mathrm{CO}_{2}$ assimilation, nitrogen adsorption (in photosynthesis), and carbon immobilization (in respiration) processes occur (Figure 1B), which decrease the number of nutrients available, thus fostering nutrient competition between the microalgae and bacteria. These two effects together ( $\mathrm{pH}$ increase and nutrient decrease) generate a hypoosmotic shock producing irreversible changes in the cell membrane and wall, and, consequently, cell lysis in pathogenic bacteria such as fecal coliforms (Enterococci and Escherichia coli), Clostridium perfringens, and Salmonella enterica [127]. In addition, some studies have determined that Synechocystis sp. and C. vulgaris produce toxins that affect the environment (raise its $\mathrm{pH}$ level). The former is known as microsistin-LR, while the latter is a toxin derived from long-chain fatty acids. These toxins kill cells due to $\mathrm{pH}$ changes [132].

Developed countries often use microalgae in the treatment of wastewater and the elimination of pathogenic bacteria. For example, Chlorella sorokiniana and Scenedesmus obliquus have been used for treating water with high organic loads and the elimination of 
pathogenic bacteria and pollutants, such as fecal coliforms, total coliforms, E. coli, Salmonella, and Shigella, managing to destroy up to $99.78 \%$ of the microorganisms $[78,133,134]$.

In addition, in recent studies, Galdieria sulphuraria (red extremophilic microalgae) has been used to reduce dissolved organic carbon, phosphates, and ammoniacal nitrogen in eutrophied waters, observing that, after four days, the nutrient concentrations and $\mathrm{pH}$ level decreased significantly (from $\mathrm{pH} 2.5$ to $\mathrm{pH} 4$ ), which removed $99 \%$ of the bacteria [135].

\subsection{Viral Inactivation}

Several pathogenic viruses associated with major disease outbreaks are commonly found in wastewater. However, conventional approaches to pathogen elimination are often associated with different economic and logistics drawbacks [76]. Conventional viral inactivation protocols use ultraviolet radiation, which in addition to being an economically unfeasible methodology, it is not equally effective for all viruses as its effectiveness depends on the type of virus genome. For example, RNA viruses are often more resistant to direct light inactivation [136]. Alternative and nontraditional systems use polysaccharides extracted from Porphyridium sp., which inhibit a large percentage of viruses, including the Human Immunodeficiency Virus (HIV 1 and 2). This viral inactivation occurs by inhibiting viral reverse transcriptase and $\mathrm{RNase} \mathrm{H}$, which are essential for the replication and synthesis of viral proteins $[132,137,138]$.

Furthermore, microalgae have recently been used for the removal of Enterovirus and Norovirus from wastewater $[139,140]$. A team of researchers from Bangladesh developed a system of algae immobilized on filter paper [141], which managed to remove $100 \%$ of the viral particles found in wastewater, and generated $3 \mathrm{~L}$ of microbiologically safe drinking water in $25 \mathrm{~min}$. In general, terms, there are only four models of viral particle removal or inactivation mechanisms.

One mechanism is mediated by direct sunlight induced by UV-B light or indirect sunlight induced by UV-A light. In the former case, viruses adsorb photons, causing damage to the capsid and proteins associated with their genetic material. The latter indirect form is related to the ROS produced during respiration and that are released by microalgae, which lead to the destruction of viral particles.

Another mechanism is the elevation of dissolved oxygen and the increase in $\mathrm{pH}$ mediated by microalgae, which is detrimental to several wastewater pathogens. In the cultivation of the Galdieria sulphuraria acidophilic microalgae, studies have been observed that these microalgae decrease wastewater $\mathrm{pH}$ levels, which, coupled with extreme temperatures and inactivation mediated by sunlight, play an important role in virus inactivation by changing the general virus load, impacting its structural proteins and improving the adsorption process.

Bioadsorption to the matrix followed by sedimentation of the microalgae biomass is considered one of the most effective mechanisms for the removal of viral particles. Virus binding is mediated by electrostatic interactions with exopolysacchariums or toxic exudates produced by microalgae. The ionization state of the carboxyl and amino groups from capsid proteins is highly dependent on $\mathrm{pH}$ levels, and conducts an electrical charge leading to the aggregation of viral particles on microalgae surfaces [142].

Predation is another important mechanism used in virus elimination. Here, the presence of heterotrophic and ciliated nanoflagellates in wastewater systems reduces virus viability [143]. In addition, predation can help remove viruses that become trapped in extracellular polymeric substances. Alternatively, the killing of virus predators and their subsequent settlement to the bottom of the water system by sedimentation may also contribute in reducing the number of wastewater viruses. Finally, microalgae also serve as the foundation for aquatic food networks as they feed on zooplankton and protozoa, specifically rotifers, copepods, and ciliates [144]. 


\section{Microalgae in Colombia}

In Colombia, water treatment systems are very common in urban settlements, whereas they are practically nonexistent in rural areas. Possibly, poor knowledge, economic technologies, and less cumbersome processes have constrained the implementation of water treatment plants in the country, resulting in pollutants being directly discharged to marshes, rivers, and reservoirs, often generating high levels of pollution, which far exceed the maximum permissible values, and negatively impacting the ecosystem and its surrounding populations. However, some promising research is currently being conducted in the country for the treatment of industrial wastewater using microalgae as bioreactors. For example, Chlorella sp. and Scenedesmus sp. in the wastewater treatment of a textile company [145,146], Synedra sp. as an inhibitor of pathogenic bacteria [147], Chlorella vulgaris and Scenedesmus acutus to remove chromium from tannery wastewater [148], Spirulina maxima; Spirulina platensis; and Chlorella vulgaris as an alternative for treating eu-trophication of the Ubaque lagoon [149], Chlorella vulgaris in the removal of organic matter in wastewater [150], Chlorella sp. for treating wastewater from the paint industry [151], Chlorella sp. for the production of biofuel from wastewater treatment [152], Chlorella sp. used in the degradation of phenol [153], Chlorella vulgaris and C. sorokiniana coupled with Azospirillum brasilense in the treatment of wastewater [154], Chlorella vulgaris used to remove nitrogen and organic matter through artificial wetlands [155], and Chlorophyta division in the biological treatment of acidic coal mine drains [156]. Despite 1695 micro-algae reports in the Colombian territory [157], majority of these studies have focused on a reduced number of species, not fully leveraging the biotechnological potential available in the country.

In addition, the microalgae have huge bioprospective potential, of importance for sustainable development, which has been studied and applied in Colombia, as the use of Chlorella sp. as a soil fertilizer [158], Scenedesmus sp. as a nutritional source for crustaceans used as food in the early stages of larviculture of freshwater $[159,160]$, the species Dunaliella salina, Chlorella sorokiniana and Chlorella vulgaris for the production of fatty acids and subsequently as a source for biodiesel [161-163], and the use of the microalgae as an improvement in the carotenoids production with the biochemical and metabolic characteristic exhibited by Dunaliella salina [164].

The diversity of ecosystems, climates and water resources present in Colombia imply great conservation commitments. In this sense, within its biodiversity there are numerous species of microalgae known and yet to be explored, which contribute to solving environmental problems and the preservation of ecosystems. Some studies have shown that there is a great diversity of microalgae $[79,85,165]$; however, there is still much to explore, to identify new species and evaluate their biotechnological potential in water treatment and other applications.

\section{Conclusions}

Phycoremediation is an environmentally sustainable technology with great potential in traditional water treatment. This approach is a living example of the Circular Economy, which is so popular right now. The cultivation and application of microalgae is a promising approach for the recovery of hard-to-reach bodies of water and populations with few resources since it not only decreases eutrophication rates and increases dissolved oxygen concentrations in the bodies of water, but also generate innovative by-products (pigments, enzymes, sugars, and lipids). Currently, several Colombian companies and universities are using this eco-friendly technology under the premise of "restoring by producing". In Colombia, a mega-diverse country with serious pollution problems, the bioprospecting, development, and application of microalgae in bodies of water would be an excellent strategy for the recovery of these ecosystems, thus improving the quality of life of their surrounding communities. 


\begin{abstract}
Author Contributions: Conceptualization, E.M.S. and Y.A.D.; validation, E.M.S. and Y.A.D.; writingoriginal draft preparation, E.M.M., L.C.G. and M.C.S.; writing-review and editing, E.M.S. and Y.A.D.; supervision, E.M.S. All authors have read and agreed to the published version of the manuscript.
\end{abstract}

Funding: This work was funded by SGR/Sucre Governorate (Grant BPIN 2017000100035).

Institutional Review Board Statement: Not applicable.

Informed Consent Statement: Not applicable.

Data Availability Statement: Data available in a publicly accessible repository. The data presented in this study are openly available in Web of Science.

Conflicts of Interest: The authors declare no conflict of interest.

\title{
References
}

1. Zabala, M.; Hernández Atilano, E. Ciénaga de Ayapel a Través de la Variación Temporal de los Aspectos morfo Funcionales del Fitoplancton y un Indicador de Calidad Ecológica; Universidad de Antioquia, Corporación Académica Ambiental: Medellín, Colombia, 2017.

2. Schmidt-Mumm, U.; Janauer, G. Seasonal dynamics of the shoreline vegetation in the Zapatosa floodplain lake complex. Colombia. Rev. Biol. Trop. 2014, 62, 1073-1097. [CrossRef] [PubMed]

3. Caballero Acosta, J.; Durango, L.C. Aproximaciones para la evaluación ambiental de los complejos cenagosos en el marco de la depresión Momposina. Gest. Ambiente 1998, 1, 27-37.

4. Moreno, M.; Aguirre, R. State of the art of limnology and flood plain lakes (swamps) in Colombia. Rev. Gestión Ambiente 2009, 12, 85-105.

5. Vivas, L.J.; Espinosa, L.F.; Parra Henríquez, L.G. Identificación de fuentes terrestres de contaminación y cálculo de las cargas de contaminantes en el área de influencia de la Ciénaga Grande de Santa Marta, caribe colombiano. Bull. Mar. Coast. Res. 2016, 42, 7-30. [CrossRef]

6. Abdel-Raouf, N.; Al-Homaidan, A.A.; Ibraheem, I.B.M. Microalgae and wastewater treatment. Saudi J. Biol. Sci. 2012, 19, 257-275. [CrossRef]

7. Granado Lorencio, C.; Serna Hernández, A.; Carvajal, J.D.; Jiménez Segura, L.F.; Gulfo, A.; Alvarez, F. Regionally nested patterns of fish assemblages in floodplain lakes of the Magdalena river (Colombia). Ecol. Evol. 2012, 2, 1296-1303. [CrossRef]

8. Lehtiniemi, M.; Engström-Öst, J.; Viitasalo, M. Turbidity decreases anti-predator behaviour in pike larvae, Esox lucius. Environ. Biol. Fishes. 2005, 73, 1-8. [CrossRef]

9. Turner, A.M.; Chislock, M.F. Blinded by the stink: Nutrient enrichment impairs the perception of predation risk by freshwater snails. Ecol. Appl. 2010, 20, 2089-2095. [CrossRef]

10. Salomón, S.; Rivera-Rondón, C.A.; Zapata, Á.M. Floraciones de cianobacterias en Colombia: Estado del conocimiento y necesidades de investigación ante el cambio global. Rev. Acad. Colomb. Cienc. Exactas Físicas Nat. 2020, 44, 376-391. [CrossRef]

11. Chislock, M.F.; Doster, E.; Zitomer, R.A.; Wilson, A.E. Eutrophication: Causes, Consequences, and Controls in Aquatic Ecosystems. Nat. Educ. Knowl. 2013, 4, 10.

12. Mancera, J.E.; Vidal, L.A. Florecimiento de microalgas relacionado con mortandad masiva de peces en el complejo lagunar Ciénaga Grande de Santa Marta, Caribe colombiano. Boletín Investig. Mar. Costeras-Invemar 1994, 23, 103-117. [CrossRef]

13. Instituto de Investigaciones Marinas y Costeras (INVEMAR) Concepto Técnico Sobre la Mortandad de Peces en la Ciénaga Grande de Santa Marta (sector Tasajera) Magdalena-CPT-CAM-011-15. 2015. Available online: https://alfresco.invemar.org.co/ share/s / ANKUYB-PSxiP8UTHa_V8uw (accessed on 23 September 2021).

14. Instituto de Investigaciones Marinas y Costeras (INVEMAR) Concepto Técnico Sobre la Mortandad de Peces en la Ciénaga Grande de Santa Marta (sector Caño Grande-Pajarales), Magdalena-CPT-CAM-022-15. 2015. Available online: http:/ / cinto.invemar.org.co/alfresco/d/d/workspace/SpacesStore/0d8b0b08-849c-43db-9c0d-3f7ec7c61676/CONCEPTO\% 20T\%C3\%89CNICO $\% 20$ SOBRE\%20MORTANDAD $\% 20$ DE $\% 20$ PECES $\% 20$ EN $\% 20 L A \% 20 C I \% C 3 \% 89 N A G A \% 20 G R A N D E \% 20$ DE\%20SANTA\%20MARTA\%20(SECTOR\%20CA\%C3\%910\%20GRANDE\%20-\%20PAJARALES),\%20OCURRIDA\%20EN\%20 NOVIEMBRE\%20DE\%202015?ticket=TICKET_92c6658f80f850fc6fa724431e054fa0fcf04812 (accessed on 23 September 2021).

15. Soto Varela, Z.; Pérez Lavalle, L.; Estrada Alvarado, D. Bacteria causing of foodborne diseases: An overview at Colombia. Salud Uninorte 2016, 32, 105-122. [CrossRef]

16. Liu, X.; He, X.; An, Z.; Sun, W.; Chen, N.; Gao, X.; Li, X.; Zhang, X. Citrobacter freundii infection in red swamp crayfish (Procambarus clarkii) and host immune-related gene expression profiles. Aquaculture 2020, 515, 734499. [CrossRef]

17. Hossain, M.I.; Neela, F.A.; Hussain, M.A.; Rahman, M.H.; Suzuki, S. Distribution of Pseudomonas aeruginosa in Swamps and it's Infection to Oreochromis niloticus. J. Bio-Sci. 1970, 14, 77-81. [CrossRef]

18. Dębowski, M.; Zieliński, M.; Kazimierowicz, J.; Kujawska, N.; Talbierz, S. Microalgae Cultivation Technologies as an Opportunity for Bioenergetic System Development-Advantages and Limitations. Sustainability 2020, 12, 9980. [CrossRef]

19. Bhatia, S.K.; Mehariya, S.; Bhatia, R.K.; Kumar, M.; Pugazhendhi, A.; Awasthi, M.K.; Atabani, A.E.; Kumar, G.; Kim, W.; Seo, S.-O.; et al. Wastewater based microalgal biorefinery for bioenergy production: Progress and challenges. Sci. Total Environ. 2021, 751, 141599. [CrossRef] [PubMed] 
20. Henkanatte-Gedera, S.M.; Selvaratnam, T.; Karbakhshravari, M.; Myint, M.; Nirmalakhandan, N.; Van Voorhies, W.; Lammers, P.J. Removal of dissolved organic carbon and nutrients from urban wastewaters by Galdieria sulphuraria: Laboratory to field scale demonstration. Algal Res. 2017, 24, 450-456. [CrossRef]

21. Panda, S.; Mishra, S.; Akcil, A.; Kucuker, M.A. Microalgal potential for nutrient-energy-wastewater nexus: Innovations, current trends and future directions. Energy Environ. 2021, 32, 604-634. [CrossRef]

22. Salbitani, G.; Carfagna, S. Ammonium Utilization in Microalgae: A Sustainable Method for Wastewater Treatment. Sustainability 2021, 13, 956. [CrossRef]

23. Di Cicco, M.R.; Iovinella, M.; Palmieri, M.; Lubritto, C.; Ciniglia, C. Extremophilic Microalgae Galdieria Gen. for Urban Wastewater Treatment: Current State, the Case of "POWER" System, and Future Prospects. Plants 2021, 10, 2343. [CrossRef]

24. Oswald, W.J.; Gotaas, H.B.; Golueke, C.G.; Kellen, W.R.; Gloyna, E.F.; Hermann, E.R. Algae in Waste Treatment [with Discussion]. Sewage Ind. Wastes 1957, 29, 437-457.

25. Barsanti, L.; Gualtieri, P. Is exploitation of microalgae economically and energetically sustainable? Algal Res. 2018, 31, 107-115. [CrossRef]

26. González, I.; Ekelhof, A.; Herrero, N.; Siles, J.Á.; Podola, B.; Chica, A.F.; Ángeles Martín, M.; Melkonian, M.; Izquierdo, C.G.; Gómez, J.M. Wastewater nutrient recovery using twin-layer microalgae technology for biofertilizer production. Water Sci. Technol. 2020, 82, 1044-1061. [CrossRef] [PubMed]

27. Zhuang, W.-Q.; Fitts, J.P.; Ajo-Franklin, C.M.; Maes, S.; Alvarez-Cohen, L.; Hennebel, T. Recovery of critical metals using biometallurgy. Curr. Opin. Biotechnol. 2015, 33, 327-335. [CrossRef]

28. Ruan, J.; Zhu, X.; Qian, Y.; Hu, J. A new strain for recovering precious metals from waste printed circuit boards. Waste Manag. 2014, 34, 901-907. [CrossRef]

29. Ju, X.; Igarashi, K.; Miyashita, S.; Mitsuhashi, H.; Inagaki, K.; Fujii, S.; Sawada, H.; Kuwabara, T.; Minoda, A. Effective and selective recovery of gold and palladium ions from metal wastewater using a sulfothermophilic red alga, Galdieria sulphuraria. Bioresour. Technol. 2016, 211, 759-764. [CrossRef]

30. Rizwan, M.; Mujtaba, G.; Memon, S.A.; Lee, K.; Rashid, N. Exploring the potential of microalgae for new biotechnology applications and beyond: A review. Renew. Sustain. Energy Rev. 2018, 92, 394-404. [CrossRef]

31. Su, Y. Revisiting carbon, nitrogen, and phosphorus metabolisms in microalgae for wastewater treatment. Sci. Total Environ. 2021, 762, 144590. [CrossRef]

32. Hussain, F.; Shah, S.Z.; Ahmad, H.; Abubshait, S.A.; Abubshait, H.A.; Laref, A.; Manikandan, A.; Kusuma, H.S.; Iqbal, M. Microalgae an ecofriendly and sustainable wastewater treatment option: Biomass application in biofuel and bio-fertilizer production. A review. Renew. Sustain. Energy Rev. 2021, 137, 110603. [CrossRef]

33. Mohsenpour, S.F.; Hennige, S.; Willoughby, N.; Adeloye, A.; Gutierrez, T. Integrating micro-algae into wastewater treatment: A review. Sci. Total Environ. 2021, 752, 142168. [CrossRef]

34. De Medeiros, V.P.B.; Pimentel, T.C.; Varandas, R.C.R.; dos Santos, S.A.; de Souza Pedrosa, G.T.; da Costa Sassi, C.F.; da Conceição, M.M.; Magnani, M. Exploiting the use of agro-industrial residues from fruit and vegetables as alternative microalgae culture medium. Food Res. Int. 2020, 137, 109722. [CrossRef] [PubMed]

35. Hultberg, M.; Bodin, H.; Ardal, E.; Asp, H. Effect of microalgal treatments on pesticides in water. Environ. Technol. 2016, 37, 893-898. [CrossRef] [PubMed]

36. Nie, J.; Sun, Y.; Zhou, Y.; Kumar, M.; Usman, M.; Li, J.; Shao, J.; Wang, L.; Tsang, D.C.W. Bioremediation of water containing pesticides by microalgae: Mechanisms, methods, and prospects for future research. Sci. Total Environ. 2020, 707, 136080. [CrossRef] [PubMed]

37. Leng, L.; Wei, L.; Xiong, Q.; Xu, S.; Li, W.; Lv, S.; Lu, Q.; Wan, L.; Wen, Z.; Zhou, W. Use of microalgae based technology for the removal of antibiotics from wastewater: A review. Chemosphere 2020, 238, 124680. [CrossRef]

38. Ubando, A.T.; Africa, A.D.M.; Maniquiz-Redillas, M.C.; Culaba, A.B.; Chen, W.-H.; Chang, J.-S. Microalgal biosorption of heavy metals: A comprehensive bibliometric review. J. Hazard. Mater. 2021, 402, 123431. [CrossRef]

39. Ahmad, N.; Mounsef, J.R.; Abou Tayeh, J.; Lteif, R. Bioremediation of Ni, $\mathrm{Al}$ and Pb by the living cells of a resistant strain of microalga. Water Sci. Technol. 2020, 82, 851-860. [CrossRef]

40. Pavithra, K.G.; Kumar, P.S.; Jaikumar, V.; Vardhan, K.H.; SundarRajan, P. Microalgae for biofuel production and removal of heavy metals: A review. Environ. Chem. Lett. 2020, 18, 1905-1923. [CrossRef]

41. Kaloudas, D.; Pavlova, N.; Penchovsky, R. Phycoremediation of wastewater by microalgae: A review. Environ. Chem. Lett. 2021, 19, 2905-2920. [CrossRef]

42. Bhatt, A.; Arora, P.; Kumar, S. Occurrence, fates and potential treatment approaches for removal of viruses from wastewater: A review with emphasis on SARS-CoV-2. J. Environ. Chem. Eng. 2020, 8, 104429. [CrossRef]

43. Ayele, A.; Getachew, D.; Kamaraj, M.; Suresh, A. Phycoremediation of Synthetic Dyes: An Effective and Eco-Friendly Algal Technology for the Dye Abatement. J. Chem. 2021, 2021, 9923643. [CrossRef]

44. Dasan, Y.K.; Lam, M.K.; Yusup, S.; Lim, J.W.; Lee, K.T. Life cycle evaluation of microalgae biofuels production: Effect of cultivation system on energy, carbon emission and cost balance analysis. Sci. Total Environ. 2019, 688, 112-128. [CrossRef] [PubMed]

45. Phang, S.-M.; Chu, W.-L.; Rabiei, R. Phycoremediation. In The Algae World; Dinabandhu, S., Seckbach, J., Eds.; Springer: Dordrecht, The Netherlands, 2015; pp. 357-389.

46. Mustafa, S.; Bhatti, H.N.; Maqbool, M.; Iqbal, M. Microalgae biosorption, bioaccumulation and biodegradation efficiency for the remediation of wastewater and carbon dioxide mitigation: Prospects, challenges and opportunities. J. Water Process Eng. 2021, 41, 102009. [CrossRef] 
47. Coimbra, R.; Escapa, C.; Vázquez, N.; Noriega-Hevia, G.; Otero, M. Utilization of Non-Living Microalgae Biomass from Two Different Strains for the Adsorptive Removal of Diclofenac from Water. Water 2018, 10, 1401. [CrossRef]

48. Al-Homaidan, A.A.; Al-Qahtani, H.S.; Al-Ghanayem, A.A.; Ameen, F.; Ibraheem, I.B.M. Potential use of green algae as a biosorbent for hexavalent chromium removal from aqueous solutions. Saudi J. Biol. Sci. 2018, 25, 1733-1738. [CrossRef] [PubMed]

49. Sun, W.; Sun, W.; Wang, Y. Biosorption of Direct Fast Scarlet 4BS from aqueous solution using the green-tide-causing marine algae Enteromorpha prolifera. Spectrochim. Acta Part A Mol. Biomol. Spectrosc. 2019, 223, 117347. [CrossRef]

50. Ali, H. Biodegradation of Synthetic Dyes-A Review. Water Air Soil Pollut. 2010, 213, 251-273. [CrossRef]

51. Katagi, T. Bioconcentration, Bioaccumulation, and Metabolism of Pesticides in Aquatic Organisms. Rev. Environ. Contam. Toxicol. 2010, 204, 1-132. [CrossRef]

52. Matamoros, V.; Uggetti, E.; García, J.; Bayona, J.M. Assessment of the mechanisms involved in the removal of emerging contaminants by microalgae from wastewater: A laboratory scale study. J. Hazard. Mater. 2016, 301, 197-205. [CrossRef]

53. Narala, R.R.; Garg, S.; Sharma, K.K.; Thomas-Hall, S.R.; Deme, M.; Li, Y.; Schenk, P.M. Comparison of Microalgae Cultivation in Photobioreactor, Open Raceway Pond, and a Two-Stage Hybrid System. Front. Energy Res. 2016, 4, 29. [CrossRef]

54. Azubuike, C.C.; Chikere, C.B.; Okpokwasili, G.C. Bioremediation techniques-classification based on site of application: Principles, advantages, limitations and prospects. World J. Microbiol. Biotechnol. 2016, 32, 180. [CrossRef]

55. United States Environmental Protection Agency (USEPA). How to Evaluate Alternative Cleanup Technologies for Underground Storage Tank Sites. 2017. Available online: https://www.epa.gov/sites/default/files/2014-03/documents/tum_ch8.pdf (accessed on 18 August 2021).

56. Huang, H.; Ye, L. Biological technologies for cHRPs and risk control. In High-Risk Pollutants in Wastewater; Hongqiang, R., Xuxiang, Z., Eds.; Elsevier: Amsterdam, The Netherlands, 2020; pp. 209-236.

57. Zhang, B.; Li, W.; Guo, Y.; Zhang, Z.; Shi, W.; Cui, F.; Lens, P.N.L.; Tay, J.H. Microalgal-bacterial consortia: From interspecies interactions to biotechnological applications. Renew. Sustain. Energy Rev. 2020, 118, 109563. [CrossRef]

58. Fuentes, J.; Garbayo, I.; Cuaresma, M.; Montero, Z.; González-del-Valle, M.; Vílchez, C. Impact of Microalgae-Bacteria Interactions on the Production of Algal Biomass and Associated Compounds. Mar. Drugs 2016, 14, 100. [CrossRef] [PubMed]

59. Xiao, R.; Zheng, Y. Overview of microalgal extracellular polymeric substances (EPS) and their applications. Biotechnol. Adv. 2016, 34, 1225-1244. [CrossRef] [PubMed]

60. Buchan, A.; LeCleir, G.R.; Gulvik, C.A.; González, J.M. Master recyclers: Features and functions of bacteria associated with phytoplankton blooms. Nat. Rev. Microbiol. 2014, 12, 686-698. [CrossRef]

61. Ramanan, R.; Kang, Z.; Kim, B.-H.; Cho, D.-H.; Jin, L.; Oh, H.-M.; Kim, H.-S. Phycosphere bacterial diversity in green algae reveals an apparent similarity across habitats. Algal Res. 2015, 8, 140-144. [CrossRef]

62. Ramanan, R.; Kim, B.-H.; Cho, D.-H.; Oh, H.-M.; Kim, H.-S. Algae-bacteria interactions: Evolution, ecology and emerging applications. Biotechnol. Adv. 2016, 34, 14-29. [CrossRef]

63. Wang, H.; Hill, R.T.; Zheng, T.; Hu, X.; Wang, B. Effects of bacterial communities on biofuel-producing microalgae: Stimulation, inhibition and harvesting. Crit. Rev. Biotechnol. 2016, 36, 341-352. [CrossRef]

64. Natrah, F.M.I.; Bossier, P.; Sorgeloos, P.; Yusoff, F.M.; Defoirdt, T. Significance of microalgal-bacterial interactions for aquaculture Rev. Aquac. 2014, 6, 48-61. [CrossRef]

65. Al-Jabri, H.; Das, P.; Khan, S.; Thaher, M.; AbdulQuadir, M. Treatment of Wastewaters by Microalgae and the Potential Applications of the Produced Biomass-A Review. Water 2020, 13, 27. [CrossRef]

66. Shahid, A.; Malik, S.; Zhu, H.; Xu, J.; Nawaz, M.Z.; Nawaz, S.; Asraful Alam, M.; Mehmood, M.A. Cultivating microalgae in wastewater for biomass production, pollutant removal, and atmospheric carbon mitigation; a review. Sci. Total Environ. 2020, 704, 135303. [CrossRef]

67. Ratha, S.K.; Prasanna, R. Bioprospecting microalgae as potential sources of "Green Energy"-challenges and perspectives (Review). Appl. Biochem. Microbiol. 2012, 48, 109-125. [CrossRef]

68. Tato, T.; Beiras, R. The Use of the Marine Microalga Tisochrysis lutea (T-iso) in Standard Toxicity Tests; Comparative Sensitivity with Other Test Species. Front. Mar. Sci. 2019, 6, 488. [CrossRef]

69. Khan, S.; Naushad, M.; Iqbal, J.; Bathula, C.; Sharma, G. Production and harvesting of microalgae and an efficient operational approach to biofuel production for a sustainable environment. Fuel 2021, 122543. [CrossRef]

70. Zhu, L.-D.; Li, Z.-H.; Guo, D.-B.; Huang, F.; Nugroho, Y.; Xia, K. Cultivation of Chlorella sp. with livestock waste compost for lipid production. Bioresour. Technol. 2017, 223, 296-300. [CrossRef] [PubMed]

71. De Carvalho, J.C.; Borghetti, I.A.; Cartas, L.C.; Woiciechowski, A.L.; Soccol, V.T.; Soccol, C.R. Biorefinery integration of microalgae production into cassava processing industry: Potential and perspectives. Bioresour. Technol. 2018, 247, 1165-1172. [CrossRef] [PubMed]

72. Miazek, K.; Brozek-Pluska, B. Effect of PHRs and PCPs on Microalgal Growth, Metabolism and Microalgae-Based Bioremediation Processes: A Review. Int. J. Mol. Sci. 2019, 20, 2492. [CrossRef] [PubMed]

73. Suresh, A.; Kumar, R.P.; Dhanasekar, D.; Thajuddin, N. Biodiversity of Microalgae in Western and Eastern Ghats, India. Pak. J. Biol. Sci. 2012, 15, 919-928. [CrossRef] [PubMed]

74. Sharma, N.K.; Rai, A.K. Biodiversity and biogeography of microalgae: Progress and pitfalls. Environ. Rev. 2011, 19, 1-15. [CrossRef]

75. Leong, Y.K.; Chang, J.-S.S. Bioremediation of heavy metals using microalgae: Recent advances and mechanisms. Bioresour. Technol. 2020, 303, 122886. [CrossRef] 
76. Metting, F.B. Biodiversity and application of microalgae. J. Ind. Microbiol. Biotechnol. 1996, 17, 477-489. [CrossRef]

77. Tirado, O.; Manjarrez, G.; Díaz, C. Caracterización ambiental de la Ciénaga de la Quinta localizada en Cartagena de Indias, Colombia, 2009-2010. Rev. UDCA Actual. Divulg. Científica 2011, 14, 2009-2010. [CrossRef]

78. Espinosa, L.F.; Ramírez, G.; Campos, N.H. Análisis de residuos de organoclorados en los sedimentos de zonas de manglar en la Ciénaga Grande de Santa Marta y la Bahía de Chengue, Caribe colombiano. Bull. Mar. Coast. Res. 2016, 24, 79-94. [CrossRef]

79. De la Hoz, M. Phytoplankton dynamics in the Ciénaga Grande de Santa Marta, Colombian Caribbean. Boletín Investig. Mar. Costeras-Invemar 2004, 33, 159-179.

80. Garcés Ordóñez, O.; Espinosa Díaz, L.F. Contaminación por hidrocarburos en sedimentos de manglar del estuario del río Mira, Pacífico colombiano, afectados por derrames de petróleo crudo. Bull. Mar. Coast. Res. 2019, 48, 159-168. [CrossRef]

81. Marrugo Negrete, J.; Pinedo-Hernández, J.; Paternina-Uribe, R.; Quiroz-Aguas, L.; Pacheco-Florez, S. Distribución espacial y evaluación de la contaminación ambiental por mercurio en la región de la Mojana, Colombia. Rev. MVZ Córdoba 2018, 23, 7062-7075. [CrossRef]

82. Chalarca Rodríguez, D.; Mejía Ruiz, R.; Aguirre Ramírez, N. Approach to the determination of the impact of the wastewater unloads of the municipality of Ayapel, on the wetland waterquality. Rev. Fac. Ing. Univ. Antioq. 2007, 40, 41-58.

83. Gracia, L.; Marrugo, J.; Alvis, E. Contaminación por mercurio en humanos y peces en el municipio de Ayapel, Córdoba, Colombia, 2009. Rev. Fac. Nac. Salud Pública 2010, 28, 118-124.

84. Aponte Estupiñán, C. Ciénaga de Ayapel, afluente hídrico en aprietos. Rev. Científica Perspect. Intel. 2018, 8, 51-62.

85. Jaramillo, L.; Aguirre, R. Spatio-temporal changes in plankton in the Ciénaga de Ayapel (Córdoba-Colombia), during the period of lower water leve. Caldasia 2012, 34, 213-226.

86. Nuñez, J.C.; Fragoso Castilla, P.J. Uso de Macroinvertebrados Acuáticos como Bioindicadores de Contaminación del Agua de la Ciénaga Mata de Palma (Colombia). Inf. Tecnol. 2019, 30, 319-330. [CrossRef]

87. Estupiñán Torres MSC, S.M.; Ávila de Navia MSC, S.L. Calidad sanitaria del agua de la Ciénaga Mata de Palma en el departamento del Cesar, Colombia. Nova 2009, 7, 85. [CrossRef]

88. Castro, L.Á. Estudio de la contaminación por pesticidas, en ecosistemas costeros en el área de Cartagena, Ciénaga de la Virgen y zona agrícola adyacente (CIOH-IAEA). Boletín Científico CIOH 1998, 18, 15-22. [CrossRef]

89. Maldonado, W.; Baldiris, I.; Díaz, J. Evaluación de la calidad del agua en la Ciénaga de la Virgen (Cartagena, Colombia). Rev. Científica Guillermo Ockham 2011, 9, 79-87.

90. Fuentes Gandara, F.; Pinedo Hernández, J.; Marrugo Negrete, J. Metales pesados en especies ícticas de la ciénaga de Mallorquín, Colombia. Espacios 2018, 39, 19.

91. Portz, L.; Manzolli, R.P.; de Andrade, C.F.F.; Villate Daza, D.A.; Bolivar Bandeira, D.A.; Alcántara-Carrió, J. Assessment of Heavy Metals Pollution ( $\mathrm{Hg}, \mathrm{Cr}, \mathrm{Cd}, \mathrm{Ni}$ ) in the Sediments of Mallorquin Lagoon-Barranquilla, Colombia. J. Coast. Res. 2020, 95, 158. [CrossRef]

92. Fuentes Gandara, F.; Pinedo Hernández, J.; Gutiérrez, E.; Marrugo Negrete, J.; Díez, S. Heavy metal pollution and toxicity assessment in Mallorquin swamp: A natural protected heritage in the Caribbean Sea, Colombia. Mar. Pollut. Bull. 2021, 167, 112271. [CrossRef]

93. Amado, J. Evaluación del Estado Actual y Propuesta de Acciones de Recuperación de la Ciénaga Miramar en el Municipio de Barrancabermeja-Santander; Universidad Pontificia Bolivariana: Bucaramanga, Colombia, 2012.

94. Tapia Larios, C.; Bertel Sevilla, A.; Lambraño, H.; Ricardo Guerra Hernández, M.; Olivero Verbel, J. Caracterización del plancton de las ciénagas del Opón y Miramar. In Perfil Ambiental de la Ciénaga Miramar, Barrancabermeja-Santander; Verbel, J.O., Ed.; Universidad de Cartagena: Cartagena, Colombia, 2015.

95. Marrugo Negrete, J.L.; Paternina Uribe, R. Evaluación de la Contaminación por Metales Pesados en la Ciénaga la Soledad y Bahía de Cispatá, Cuenca del Bajo Sinú, Departamento de Córdoba; Facultad de Ciencias Básicas, Universidad de Córdoba: Montería, Colombia, 2011.

96. Blanco-Muñoz, E.; De la Parra-Guerra, A.C.; García-Alzate, C.; Villarreal-Blanco, E. Análisis físico-químico y fitoplanctónico de la ciénaga Puerto Caimán, vertiente Caribe, Colombia. Intropica 2020, 15, 114-125. [CrossRef]

97. Lans, C.E.; Díaz, P.B.; Paez, M.M. Compuestos organoclorados residuales en dos especies ícticas de la Ciénaga Grande del Bajo Sinú, Córdoba, Colombia. Rev. MVZ Cordoba 2011, 16, 2402-2409. [CrossRef]

98. Mogollón, M.; Aycardi, M.P.; Galeano, J.; Villalobos, J.; Arango, C. Variación espacio-temporal de las cianoprocariotas del antiguo delta del río Sinú, Córdoba, Colombia. Intropica 2014, 9, 92-101. [CrossRef]

99. Gómez-Jacinto, V.; García-Barrera, T.; Gómez-Ariza, J.L.; Garbayo-Nores, I.; Vílchez-Lobato, C. Elucidation of the defence mechanism in microalgae Chlorella sorokiniana under mercury exposure. Identification of $\mathrm{Hg}$-phytochelatins. Chem. Biol. Interact. 2015, 238, 82-90. [CrossRef]

100. Sivasubramanian, V.; Subramanian, V.V.; Muthukumaran, M. Bioremediation of chromesludge from an electroplating industry using the micro alga Desmococcus olivaceus-A pilot study. Algal Biomass 2010, 1, 104-128.

101. Yen, H.W.; Chen, P.W.; Hsu, C.Y.; Lee, L. The use of autotrophic Chlorella vulgaris in chromium (VI) reduction under different reduction conditions. J. Taiwan Inst. Chem. Eng. 2017, 74, 1-6. [CrossRef]

102. Sjahrul, M.; Arifin, D. Phytoremediation of $\mathrm{Cd}^{2+}$ by Marine Phytoplanktons, Tetracelmis chuii and Chaetoceros calcitrans. Int. J. Chem. 2012, 4, 69-74. [CrossRef]

103. Ferreira, L.S.; Rodrigues, M.S.; de Carvalho, J.C.M.; Lodi, A.; Finocchio, E.; Perego, P.; Converti, A. Adsorption of Ni ${ }^{2+}, \mathrm{Zn}^{2+}$ and $\mathrm{Pb}^{2+}$ onto dry biomass of Arthrospira (Spirulina) platensis and Chlorella vulgaris. I. Single metal systems. Chem. Eng. J. 2011, 173, 326-333. [CrossRef] 
104. Chen, C.Y.; Chang, H.W.; Kao, P.C.; Pan, J.L.; Chang, J.S. Biosorption of cadmium by CO 2-fixing microalga Scenedesmus obliquus CNW-N. Bioresour. Technol. 2012, 105, 74-80. [CrossRef] [PubMed]

105. Shanab, S.; Essa, A.; Shalaby, E. Bioremoval capacity of three heavy metals by some microalgae species (Egyptian isolates). Plant Signal. Behav. 2012, 7, 392-399. [CrossRef] [PubMed]

106. Kumar, V.; Behl, R.K.; Narula, N. Effect of phosphate-solubilizing strains of Azotobacter Chroococcum on yield traits and their survival in the rhizosphere of wheat genotypes under field conditions. Acta Agron. Hung. 2001, 49, 141-149. [CrossRef]

107. García-Galán, M.J.; Monllor-Alcaraz, L.S.; Postigo, C.; Uggetti, E.; López de Alda, M.; Díez-Montero, R.; García, J. Microalgae-based bioremediation of water contaminated by pesticides in peri-urban agricultural areas. Environ. Pollut. 2020, 265, 114579. [CrossRef]

108. Priyadarshani, I.; Sahu, D.; Rath, B. Microalgal bioremediation: Current practices and perspectives. J. Biochem. Tech. 2011, 3, $299-304$.

109. Ardal, E. Phycoremediation of Pesticides Using Microalgae; Faculty of Landscape Architecture, Horticulture and Crop Production Science, Swedish University of Agricultural Sciences: Alnarp, Sweden, 2014.

110. Singhal, M.; Jadhav, S.V.; Sonone, S.S.; Sankhla, M.S. Microalgae Based Sustainable Bioremediation of Water Contaminated by Pesticides. Biointerface Res. Appl. Chem. 2021, 12, 149-169. [CrossRef]

111. Rempel, A.; Gutkoski, J.P.; Nazari, M.T.; Biolchi, G.N.; Cavanhi, V.A.F.; Treichel, H.; Colla, L.M. Current advances in microalgae-based bioremediation and other technologies for emerging contaminants treatment. Sci. Total Environ. 2021, 772, 144918. [CrossRef]

112. Avila, R.; Peris, A.; Eljarrat, E.; Vicent, T.; Blánquez, P. Biodegradation of hydrophobic pesticides by microalgae: Transformation products and impact on algae biochemical methane potential. Sci. Total Environ. 2021, 754, 142114. [CrossRef] [PubMed]

113. Nanda, M.; Kumar, V.; Fatima, N.; Pruthi, V.; Verma, M.; Chauhan, P.K.; Vlaskin, M.S.; Grigorenko, A.V. Detoxification mechanism of organophosphorus pesticide via carboxylestrase pathway that triggers de novo TAG biosynthesis in oleaginous microalgae. Aquat. Toxicol. 2019, 209, 49-55. [CrossRef] [PubMed]

114. Nicodemus, T.J.; DiRusso, C.C.; Wilson, M.; Black, P.N. Reactive Oxygen Species (ROS) mediated degradation of organophosphate pesticides by the green microalgae Coccomyxa subellipsoidea. Bioresour. Technol. Rep. 2020, 11, 100461. [CrossRef]

115. Sutherland, D.L.; Ralph, P.J. Microalgal bioremediation of emerging contaminants-Opportunities and challenges. Water Res. 2019, 164, 114921. [CrossRef] [PubMed]

116. Xiong, Q.; Hu, L.X.; Liu, Y.S.; Zhao, J.L.; He, L.Y.; Ying, G.G. Microalgae-based technology for antibiotics removal: From mechanisms to application of innovational hybrid systems. Environ. Int. 2021, 155, 106594. [CrossRef]

117. Yu, Y.; Zhou, Y.; Wang, Z.; Torres, O.L.; Guo, R.; Chen, J. Investigation of the removal mechanism of antibiotic ceftazidime by green algae and subsequent microbic impact assessment. Sci. Rep. 2017, 7, 4168. [CrossRef]

118. Yu, F.; Ge, F.; Zhou, W.; Tao, N.; Liang, Z.; Zhu, L. Subcellular distribution of fluoranthene in Chlorella vulgaris with the presence of cetyltrimethylammonium chloride. Chemosphere 2013, 90, 929-935. [CrossRef]

119. Echeveste, P.; Agustí, S.; Dachs, J. Cell size dependent toxicity thresholds of polycyclic aromatic hydrocarbons to natural and cultured phytoplankton populations. Environ. Pollut. 2010, 158, 299-307. [CrossRef]

120. Abdel-Shafy, H.I.; Mansour, M.S.M. A review on polycyclic aromatic hydrocarbons: Source, environmental impact, effect on human health and remediation. Egypt. J. Pet. 2016, 25, 107-123. [CrossRef]

121. Sartoros, C.; Yerushalmi, L.; Béron, P.; Guiot, S.R. Effects of surfactant and temperature on biotransformation kinetics of anthracene and pyrene. Chemosphere 2005, 61, 1042-1050. [CrossRef] [PubMed]

122. Semple, K.T.; Cain, R.B.; Schmidt, S. Biodegradation of aromatic compounds by microalgae. FEMS Microbiol. Lett. 1999, 170, 291-300. [CrossRef]

123. Ghosal, D.; Ghosh, S.; Dutta, T.K.; Ahn, Y. Current State of Knowledge in Microbial Degradation of Polycyclic Aromatic Hydrocarbons (PAHs): A Review. Front. Microbiol. 2016, 7, 1369. [CrossRef]

124. El-Sheekh, M.M.; Ghareib, M.; EL-Souod, G.A. Biodegradation of Phenolic and Polycyclic Aromatic Compounds by Some Algae and Cyanobacteria. J. Bioremediat. Biodegrad. 2012, 3. [CrossRef]

125. Warshawsky, D.; Cody, T.; Radike, M.; Reilman, R.; Schumann, B.; LaDow, K.; Schneider, J. Biotransformation of benzo[a]pyrene and other polycyclic aromatic hydrocarbons and heterocyclic analogs by several green algae and other algal species under gold and white light. Chem. Biol. Interact. 1995, 97, 131-148. [CrossRef]

126. Cerniglia, C.E.; Gibson, D.T.; Van Baalen, C. Naphthalene Metabolism by Diatoms Isolated from the Kachemak Bay Region of Alaska. Microbiology 1982, 128, 987-990. [CrossRef]

127. Cerniglia, C.E.; Van Baalen, C.; Gibson, D.T. Metabolism of Naphthalene by the Cyanobacterium Oscillatoria sp., Strain JCM. Microbiology 1980, 116, 485-494. [CrossRef]

128. Tomar, R.S.; Jajoo, A. Enzymatic pathway involved in the degradation of fluoranthene by microalgae Chlorella vulgaris. Ecotoxicology 2021, 30, 268-276. [CrossRef]

129. Semple, K.T.; Cain, R.B. Biodegradation of phenols by the alga Ochromonas danica. Appl. Environ. Microbiol. 1996, 62, 1265-1273. [CrossRef]

130. Al-Gheethi, A.A.; Mohamed, R.M.; Jais, N.M.; Efaq, A.N.; Halid, A.A.; Wurochekke, A.A.; Amir-Hashim, M.K. Influence of pathogenic bacterial activity on growth of Scenedesmus sp. and removal of nutrients from public market wastewater. J. Water Health 2017, 15, 741-756. [CrossRef]

131. Molinuevo-Salces, B.; Riaño, B.; Hernández, D.; García-González, M.C. Microalgae and wastewater treatment: Advantages and disadvantages. In Microalgae Biotechnology for Development of Biofuel and Wastewater Treatment; Springer: Singapore, 2019; pp. 505-533. ISBN 9789811322648. 
132. Chai, W.S.; Tan, W.G.; Halimatul Munawaroh, H.S.; Gupta, V.K.; Ho, S.H.; Show, P.L. Multifaceted roles of microalgae in the application of wastewater biotreatment: A review. Environ. Pollut. 2021, 269, 116236. [CrossRef] [PubMed]

133. Gupta, S.K.; Ansari, F.A.; Shriwastav, A.; Sahoo, N.K.; Rawat, I.; Bux, F. Dual role of Chlorella sorokiniana and Scenedesmus obliquus for comprehensive wastewater treatment and biomass production for bio-fuels. J. Clean. Prod. 2016, 115, 255-264. [CrossRef]

134. Sebastian, S.; Nair, K.V.K. Total removal of coliforms and E. coli from domestic sewage by high-rate pond mass culture of Scenedesmus obliquus. Environ. Pollut. Ser. A Ecol. Biol. 1984, 34, 197-206. [CrossRef]

135. Delanka-Pedige, H.M.K.; Munasinghe-Arachchige, S.P.; Cornelius, J.; Henkanatte-Gedera, S.M.; Tchinda, D.; Zhang, Y.; Nirmalakhandan, N. Pathogen reduction in an algal-based wastewater treatment system employing Galdieria sulphuraria. Algal Res. 2019, 39, 101423. [CrossRef]

136. Verbyla, M.E.; Mihelcic, J.R. A review of virus removal in wastewater treatment pond systems. Water Res. 2015, 71, 107-124. [CrossRef] [PubMed]

137. Talyshinsky, M.M.; Souprun, Y.Y.; Huleihel, M.M. Anti-viral activity of red microalgal polysaccharides against retroviruses Cancer Cell Int. 2002, 2, 8. [CrossRef] [PubMed]

138. Kremer, B.P. Marine Algae in Pharmaceutical Science. Phycologia 1980, 19, 168-169. [CrossRef]

139. Delanka-Pedige, H.M.K.; Munasinghe-Arachchige, S.P.; Zhang, Y.; Nirmalakhandan, N. Bacteria and virus reduction in secondary treatment: Potential for minimizing post disinfectant demand. Water Res. 2020, 177, 115802. [CrossRef] [PubMed]

140. Delanka-Pedige, H.M.K.; Cheng, X.; Munasinghe-Arachchige, S.P.; Abeysiriwardana-Arachchige, I.S.A.; Xu, J.; Nirmalakhandan, N.; Zhang, Y. Metagenomic insights into virus removal performance of an algal-based wastewater treatment system utilizing Galdieria sulphuraria. Algal Res. 2020, 47, 101865. [CrossRef]

141. Gustafsson, O.; Manukyan, L.; Gustafsson, S.; Tummala, G.K.; Zaman, S.; Begum, A.; Alfasane, M.A.; Siddique-e-Rabbani, K.; Mihranyan, A. Scalable and Sustainable Total Pathogen Removal Filter Paper for Point-of-Use Drinking Water Purification in Bangladesh. ACS Sustain. Chem. Eng. 2019, 7, 14373-14383. [CrossRef]

142. Templeton, M.R.; Andrews, R.C.; Hofmann, R. Particle-Associated Viruses in Water: Impacts on Disinfection Processes. Crit. Rev. Environ. Sci. Technol. 2008, 38, 137-164. [CrossRef]

143. Miki, T.; Jacquet, S. Complex interactions in the microbial world: Underexplored key links between viruses, bacteria and protozoan grazers in aquatic environments. Aquat. Microb. Ecol. 2008, 51, 195-208. [CrossRef]

144. Flynn, K.J.; Kenny, P.; Mitra, A. Minimising losses to predation during microalgae cultivation. J. Appl. Phycol. 2017, 29, 1829-1840. [CrossRef]

145. Vacca Jimeno, V.A.; Angulo Mercado, E.R.; Puentes Ballesteros, D.M.; Torres Yépez, J.G.; Plaza Vega, M.E. Uso de la micro-alga Chlorella sp. viva en suspensión en la decoloración del agua residual de una empresa textil/Using the microalgae Chlorella sp. live suspended in decoloration wastewater from a textile factory. Prospectiva 2017, 15, 93-99. [CrossRef]

146. Pérez Silva, K.R.; Vega Bolaños, A.M.; Hernández Rodríguez, L.C.; Parra Ospina, D.A.; Ballen Segura, M.Á. Uso de Scenedesmus para la remoción de metales pesados y nutrientes de aguas residuales para la industria textil. Ing Solidar. 2016, 12, 95-105. [CrossRef]

147. Nuñez, D.; Serrano, J.; Otalora, L.; Rerez, R. Microalgas presentes en Rio Negro entre los Municipios de Utica y Sasaima, Cundinamarca y su utilidad en medicina Microalgae. Línea Vida 2018, 2, 1-11. [CrossRef]

148. Ardila, L.; Godoy, R.; Montenegro, L. Sorption Capacity Measurement of Chlorella vulgaris and Scenedesmus acutus to Re-move Chromium from Tannery Waste Water. IOP Conf. Ser. Earth Environ. Sci. 2017, 83, 012031. [CrossRef]

149. Romero-Morales, M.A.; Ortiz-Villota, M.T.; Meza-Rodríguez, L.D. La biorremediación con microalgas (Spirulina máxima, Spirulina platensis y Chlorella vulgaris) como alternativa para tratar la eutrofización de la laguna de Ubaque, Colombia. Rev. Investig. Desarro. E Innovación 2018, 9, 163-176. [CrossRef]

150. Sandoval Herrera, J.A.; Malo Malo, B.O.; Cartagena Arévalo, J.C.; Rubio Fernández, D. Evaluación a nivel laboratorio de la capacidad de remoción de materia orgánica de Chlorella vulgaris en las aguas residuales de la PTAR Salitre. Rev. Mutis 2018, 8 , 34-42. [CrossRef]

151. Angulo, M.E.; Castellar, O.G.; Cely, B.M.M.; Ibáñez, S.L.; Prasca, M.L. Decoloración de aguas residuales de una industria de pinturas por la microalga Chlorella sp. Rev. MVZ Córdoba 2017, 5706-5717. [CrossRef]

152. Gómez Santos, J.A.; Rodríguez González, L.G. Obtención de biomasa de microalgas en aguas residuales para la producción de biocombustibles. Renov. Rev. Estud. Interdiscip. Ciencias Soc. Tecnol. E Innovación 2019, 3, 21-36.

153. Mora-Salguero, D.; Vives Florez, M.J.; Husserl Orjuela, J.; Fernández-Niño, M.; González Barrios, A.F. Evaluation of the phenol degradation capacity of microalgae-bacteria consortia from the bay of Cartagena, Colombia. TecnoLógicas 2019, 22, 149-158. [CrossRef]

154. De-Bashan, L.E.; Bashan, Y. Bacterias promotoras de crecimiento de microalgas: Una nueva aproximación en el tratamiento de aguas residuales. Rev. Colomb. Biotecnol. 2003, 5, 85-90.

155. Leani, K.; García, Q.; Patricia, D.; Zúñiga, R.; Elena, M.; Duque, G.; Amir, J.; Rojas, A. Artículo de Investigación Evaluación de la remoción de nitrógeno y materia orgánica a través de humedales artificiales de flujo subsuperficial, acoplados a reacto-res de lecho fijo con microalgas en la Institución Universitaria Colegio Mayor de Antioquia. Rev. Ing. Región 2021, 25, 82-94. [CrossRef]

156. Torres, D.D.; Cáceres Sepúlveda, S.; Roa, A.L.; Suárez Gelvez, J.H.; Urbina Suárez, N.A. Utilización de microalgas de la divi-sión Chlorophyta en el tratamiento biológico de drenajes ácidos de minas de carbón. Rev. Colomb. Biotecnol. 2017, 19, 95-104. [CrossRef]

157. Guiry, M.D.; Guiry, G.M.; Morrison, L.; Rindi, F.; Miranda, S.V.; Mathieson, A.C.; Parker, B.C.; Langangen, A.; John, D.M.; Bárbara, I.; et al. AlgaeBase: An On-line Resource for Algae. Cryptogam. Algol. 2014, 35, 105-115. [CrossRef]

158. Ortiz-Moreno, M.L.; Sandoval-Parra, K.X.; Solarte-murillo, L.V. Chlorella, um potencial biofertilizante? Orinoquia 2019, 23, 71-78. [CrossRef] 
159. Ramírez-Merlano, J.; Mira-López, T.; Cruz-Casallas, P. Effect of light intensity on reproductive efficiency of cladoceran Moina sp., under laboratory conditions. Orinoquia 2013, 17, 117-182. [CrossRef]

160. Jaramillo-campaña, H.A.; Calpa, N.C.; Gómez-nieves, V.Y. Evaluación del periodo de llenado y evacuación intestinal de Brachionus calyciflorus alimentado con Chlorella sp. Orinoquia 2019, 23, 41-47. [CrossRef]

161. Tejeda-Benítez, L.; Henao-Argumedo, D.; Alvear-Alayón, M.; Castillo-Saldarriaga, C.R. Caracterización y perfil lipídico de aceites de microalgas. Rev. Fac. Ing. 2015, 24, 43. [CrossRef]

162. Ortiz-Moreno, M.L.; Cortés-Castillo, C.E.; Sánchez-Villarraga, J.; Padilla, J.; Otero-Paternina, A.M. Evaluación del crecimiento de la mi-croalga chlorella sorokiniana en diferentes medios de cultivo en condiciones autotróficas y mixotróficas. Orinoquia $2013,17,2$.

163. Malagón-Micán, M.; Suárez-Chaparro, M. Influencia de la concentración inicial de Chlorella vulgaris y $\mathrm{CO}_{2}$ en la producción de lípidos. Rev. Lasallista Investig. 2000, 17, 59-69. [CrossRef]

164. Gallego-Cartagena, E.; Castillo-Ramírez, M.; Martínez-burgos, W. Effect of stressful conditions on the carotenogenic activity of a Colombian strain of Dunaliella salina. Saudi J. Biol. Sci. 2019, 26, 1325-1330. [CrossRef] [PubMed]

165. Duque, S.R.; Núñez-Avellaneda, M. Microalgas acuáticas de la Amazonía colombiana. Biota Colomb. 2000,1 , 216. 